\title{
WTO Jurisprudence
}

This book offers a critical examination of the jurisprudence of the World Trade Organization (WTO) as an emancipatory international social contract on trade.

The book suggests that the WTO is an international organization built and operating on member states' attribution of authority through consent with legislative, administrative, and adjudicative functions - three functions in one triune personality. With a solid constitutional continuity building on GATT experiences, the WTO has successfully made governments accountable to foreign individuals in various capacities either as traders of goods, providers of services, or holders of intellectual property rights within the global marketplace. With a triune personality, the WTO operates within the reign of state primacy - the force - ultimately for the benefits of individuals - the ends - in the global marketplace, and gains a soul of its own in the institutional evolution - the means - of the global trading regime. Although the tripartite dynamics between states, international institutions, and individuals in the global marketplace are unprecedentedly complex, the WTO's ends of benefiting individuals in the global marketplace has no end. Beyond the critical analysis of WTO's decisionmaking by consensus, the book critically examines GATT's "common intention" treaty interpretation, Antidumping's NME methodology, TRIPS' public health concerns, and IP-competition trade policy dynamics. A unified WTO jurisprudence looking at the WTO as an international social contract on trade is therefore proposed to allow a fresh look at the force, the means, and the ends of the constitutional evolution of the global trading regime.

Wenwei Guan is an Associate Professor of Law at City University of Hong Kong. 


\section{Routledge Research in International Law}

Russian Discourses on International Law

Sociological and Philosophical Phenomenon

Edited by P. Sean Morris

Backstage Practices in Transnational Law

Lianne J.M Boer and Sofia Stolk

International 'Criminal' Responsibility

Antinomies

Ottavio Quirico

The Future of International Courts

Regional, Institutional and Procedural Challenges

Edited by Avidan Kent, Nikos Skoutaris and Jamie Trinidad

The Far-Right in International and European Law

Natalie Alkiviadou

International Law and Revolution

Owen Taylor

The Responsibility to Protect in International Law

Philosophical Investigations

Natalie Oman

The Responsibility to Protect in Libya and Syria

Mass Atrocities, Human Protection, and International Law

rasmine Nablawi

Public Private Partnership Contracts

The Middle East and North Africa

Mohamed Ismail

WTO Jurisprudence

Governments, Private Rights, and International Trade

Wenwei Guan

State Territory and International Law

Josephat Ezenwajiaku

For more information about this series, please visit www.routledge.com/Routle dge-Research-in-International-Law/book-series/INTNLLAW 


\section{WTO Jurisprudence \\ Governments, Private Rights, and International Trade}

\section{Wenwei Guan}


First published 2020

by Routledge

2 Park Square, Milton Park, Abingdon, Oxon OXI4 4RN

and by Routledge

52 Vanderbilt Avenue, New York, NY 10017

Routledge is an imprint of the Taylor \& Francis Group, an informa business

(c) 2020 Wenwei Guan

The right of Wenwei Guan to be identified as author of this work has been asserted by him in accordance with sections 77 and 78 of the Copyright, Designs and Patents Act 1988.

All rights reserved. No part of this book may be reprinted or reproduced or utilised in any form or by any electronic, mechanical, or other means, now known or hereafter invented, including photocopying and recording, or in any information storage or retrieval system, without permission in writing from the publishers.

Trademark notice: Product or corporate names may be trademarks or registered trademarks, and are used only for identification and explanation without intent to infringe.

British Library Cataloguing-in-Publication Data

A catalogue record for this book is available from the British Library

Library of Congress Cataloging-in-Publication Data

Names: Guan, Wenwei, author.

Title: WTO jurisprudence : governments, private rights and international trade / Wenwei Guan.

Description: Abingdon, Oxon ; New York, NY : Routledge, 2020. |

Series: Routledge research in international law | Includes

bibliographical references and index.

Identifiers: LCCN 2020003549 (print) | LCCN 2020003550 (ebook)

Subjects: LCSH: Foreign trade regulation. | World Trade Organization. Classification: LCC K3943 . G83 2020 (print) | LCC K3943 (ebook) | DDC 343.08/7-dc23

LC record available at https://lccn.loc.gov/2020003549

LC ebook record available at https://lccn.loc.gov/2020003550

ISBN: 978-0-367-42876-1 (hbk)

ISBN: 978-0-367-85566-6 (ebk)

Typeset in Galliard

by Swales \& Willis, Exeter, Devon, UK 
To Emma, Adam, and Isobel 
$\because$ Taylor \& Francis

Taylor \& Francis Group

http://taylorandfrancis.com 


\section{Contents}

Foreword by Prof. Ernst-Ulrich Petersmann ix

Preface and acknowledgments xii

$1 \quad$ International social contract on trade: its force, means, and ends $\quad 1$

1.1 History and evolution from the GATT to the WTO 1

1.2 States, the WTO, and the individuals in international law 6

1.3 WTO as an international social contract on trade 17

1.4 Conclusion 25

2 WTO decision-making by consensus

2.1 Introduction 30

2.2 The WTO decision-making duet: consensus and single undertaking 33

2.3 Consensus principle's undesirable practical implications 40

2.4 Consensus's contractarian deficits and WTO legitimacy 49

2.5 Conclusion: consensus yet consented? 59

3 GATT: the "common intention" approach of treaty interpretation

3.1 Introduction 68

3.2 How general should the GATT general exceptions be? 71

3.3 Judicial activist "common intention" approach of treaty interpretation 80

3.4 The legitimacy deficit of the "common intention" approach 99

3.5 Concluding remarks 106

4 Antidumping: the NME normal value determination

4.1 Introduction 112

4.2 Antidumping development and normal value determination 116 
viii Contents

4.3 The NME methodology: nationality as status of products in trade 122

4.4 From status to contract and back: NME treatment and beyond 129

4.5 Conclusion 137

5 TRIPS: IPRs, public health, and international trade

5.1 Introduction 142

5.2 WTO to promote public health through international trade 145

5.3 Public bealth caught in TRIPS' birth defect 153

5.4 Public health, IPRs, and trade: the private right dilemma in international law 165

5.5 Conclusion: the dynamics between public health, IPRs, and trade 174

6 Trade and policy: IP-competition dynamics in TRIPS' FRAND enforcement

6.1 Introduction 180

6.2 Harmonized TRIPS $v$. diversified FRAND enforcement 183

6.3 SEPs, antitrust, and trade in WTO law 195

6.4 Concluding remarks 211

7 Ends without end: the future prospects of WTO evolution

Index 


\section{Foreword}

Since China's accession to the World Trade Organization (WTO) in 2001, China has complied with most WTO rules and most WTO dispute settlement findings involving China as a complainant or defendant. Yet due to the US initiation of a "trade war" against China and of other, illegal US measures disrupting the WTO legal and dispute settlement system, justifying compliance with WTO rules and WTO dispute settlement findings has become more controversial. A breakdown of the WTO trading, legal, and dispute settlement systems will adversely affect the national interests of all 164 WTO members; it is also likely to render realization of the UN sustainable development goals (SDGs) and climate change prevention impossible. Hence, it remains an important task for governments, academics, and civil societies to explain why compliance with WTO rules and dispute settlement findings is in the reasonable self-interests of all WTO members and their citizens. This monograph by Professor Wenwei Guan offers an important contribution to defending "public reason" in the current WTO governance and dispute settlement crises.

The power-oriented system of "international law among sovereign states" since the peace treaties of Westphalia (1648) was justified by the consent of states. Since the 1945 United Nations (UN) Charter and the 1948 Universal Declaration of Human Rights, however, international law and the UN legal systems are also justified by the universal acceptance of "inalienable" and "indivisible" human rights, popular self-determination of peoples, and universally agreed SDGs. Chapter 1 of this book convincingly explains why state consent and the universal recognition of treaties, customary law, and general principles of law as "sources" of modern international law no longer suffice for explaining and justifying WTO law. For example, the "blocking" of the filling of vacancies of WTO Appellate Body members violates both WTO law (e.g. Article 17 of the Dispute Settlement Understanding, Article IX:1 WTO Agreement) and the limited, democratic mandates given by national parliaments for implementing the WTO Agreements. Chapter 1 further acknowledges that - just as the UN SDGs are defined in terms of promoting human rights and related public goods (like poverty reduction, climate change mitigation, and protection of the environment) - also the sustainable development goals of WTO law and "principles of justice" underlying the WTO dispute settlement system (e.g. violation 
complaints, non-violation complaints and situation complaints pursuant to GATT Article XXIII) are ultimately aimed at protecting transnational rule of law and other public goods for the benefit of citizens and peoples in WTO member states. As WTO law admits sub-national customs territories (like Hong Kong, Macau, and Taiwan) and supra-national WTO members (like the European Union) and protects also individual rights (e.g. intellectual property rights) and remedies (e.g. of individual access to domestic judicial remedies), Chapter 1 describes the "WTO as an international social contract on trade" constituting legislative, executive, and judicial institutions deriving their limited legal powers from the consent of states and related international law principles (like good faith, pacta sunt servanda, limited delegation of powers), yet aiming at protecting legal and economic benefits not only for all WTO member governments, but also for their citizens and peoples. This multilevel governance system is currently confronted with illegal power politics threatening its social legitimacy and the welfare of citizens all over the world.

Chapter 2 discusses the many legal and policy problems of WTO decisionmaking by consensus and the political abuses of veto powers. As WTO law explicitly provides for majoritarian decision-making on administrative and judicial matters, the current WTO governance failures to protect the WTO legal and dispute settlement systems (e.g. through majoritarian filling of WTO Appellate Body vacancies) against illegal abuses of US veto powers undermine the legal, democratic, and social legitimacy and accountability of the WTO. Chapters 3 to 6 offer case studies, for instance criticizing the "common intention" approach to treaty interpretation in the Appellate Body jurisprudence (Chapter 3 ), adverse effects on private rights in WTO jurisprudence relating to discriminatory antidumping measures (Chapter 4 ), and intellectual property rights (Chapters 5 and 6). These case studies elaborate important policy recommendations for improving rule of law and non-discriminatory conditions of competition in the world trading system, for instance by mandating the WTO Working Group on Trade and Competition to elaborate more coherent WTO competition rules and "flexibilities" for protecting public health and technological innovation. Chapter 7 concludes with a critical discussion of the "state primacy paradox" undermining WTO governance for the benefit of citizens, thereby confirming the need for more coherent theories of WTO diplomacy, WTO governance, WTO jurisprudence, and their constitutional foundations.

The hegemonic US assault on the WTO legal and dispute settlement systems risks provoking a disintegration of the world trading system, for instance by inducing China to prioritize its bilateral and regional economic cooperation agreements (like China's Belt and Road agreements with more than 60 countries, its Regional Comprehensive Economic Partnership) similar to China's prioritization of "cyber sovereignty" in internet governance systems. Hopefully, Professor Wenwei Guan's thought-provoking book will induce other Asian scholars to undertake similar studies on how to improve multilevel governance and limit accountability failures in the WTO. The "emancipatory evolution" of WTO governance beyond "state consent" - and the "pluralization" of legal 
forms of multilevel governance of transnational public goods (like a mutually beneficial world trading system, climate change mitigation, transnational rule of law) - require going beyond "methodological nationalism" justifying poweroriented paradigms of states (e.g. China's totalitarian communist party state) that hamper UN/WTO institutions, WTO law, and WTO governance. Modern international law and multilevel governance function not only as (1) positive multilevel legal orders (e.g. based on legal recognition of rules, principles, and institutions for legislative, executive, judicial, civic, economic, and social decision-making processes); they also (2) dynamically evolve as legal practices interacting with, clarifying, and developing past understandings of the law, which remain (3) embedded into social and cultural infrastructures (like agreed "principles of justice") driven by rational and non-rational actors and their multiple discourses. The customary rules of treaty interpretation explicitly require clarifying the treaty terms not only in their context (e.g. including subsequent practices) with due regard to their object and purpose, but also "in conformity with the principles of justice" underlying international law, including also "human rights and fundamental freedoms for all" (cf. the Preamble and Article 31 VCLT). Judicial administration of justice in disputes over the meaning and application of modern international law must protect both legal input and output legitimacy of dispute settlement in order to promote social legitimacy of third-party adjudication and voluntary rule-compliance. Promoting the UN and WTO objectives of "sustainable development" will require far-reaching adjustments of international trade and environmental law, governance institutions, legal practices, and social agreements on "principles of justice" (e.g. justifying multilevel governance of public goods). The necessary reforms will benefit from critical analyses of the current governance, dispute settlement and legitimacy crises (e.g. in the UN and WTO), including from the critical studies of Professor Wenwei Guan. The fact that the British "(Br)exit" from the European Union and the disregard for WTO law by the US Trump administration are initiated by the two oldest "liberal democracies" reveals another lesson for protecting rules-based trading systems: not only authoritarian state-capitalism, but also neo-liberalism protecting "unequal freedoms" (like "Chicago school economics" for liberalization, deregulation and privatization of markets) lead to socially disruptive injustices that must be avoided by ordo-liberal limitations of "market failures" and "governance failures" in order to construct transnational "social market economies" supported by free and reasonable citizens with more equal and more equitable opportunities and social safeguards.

Prof. Ernst-Ulrich Petersmann

Geneva

World Trade Organization

December 2019 


\section{Preface and acknowledgments}

This book offers a critical examination of the jurisprudence of the World Trade Organization (WTO) as an emancipatory international social contract on trade. The book suggests that the WTO is an international organization built and operating on member states' attribution of authority through consent with legislative, administrative, and adjudicative functions - three functions in one triune personality. With a solid constitutional continuity building on GATT experiences, the WTO has successfully made governments accountable to foreign individuals in various capacities either as traders of goods, providers of services, or holders of intellectual property rights within the global marketplace. With a triune personality, the WTO operates within the reign of state primacy - the force - ultimately for the benefits of individuals - the ends - in the global marketplace, and gains a soul of its own in the institutional evolution - the means - of the global trading regime. Although the tripartite dynamics between states, international institutions, and individuals in the global marketplace are unprecedentedly complex, the WTO's ends of benefiting individuals in the global marketplace has no end. Beyond the critical analysis of WTO's decisionmaking by consensus, the book critically examines GATT's "common intention" treaty interpretation, Antidumping's NME methodology, TRIPS' public health concerns, and IP-competition trade policy dynamics. A unified WTO jurisprudence looking at the WTO as an international social contract on trade is therefore proposed to allow a fresh look at the force, the means, and the ends of the constitutional evolution of the global trading regime.

I would like to take this opportunity to thank Prof. Ernst-Ulrich Petersmann, an eminent scholar in the field whose works have continuously inspired my research for so many years. Prof. Petersmann's works articulate the categorical imperative of the WTO with great philosophical depth, which to a great extent presents how beautiful the WTO could be as an emancipatory force benefiting individuals in the global marketplace. When I asked for a Foreword upon my completion of the first draft, his confirmation and enthusiastic support were invaluable to me. I am very grateful.

I would also like to thank Prof. Theresa Kaiser-Jarvis from the University of Michigan Law School, and Barbara H. Garavaglia, Seth Quidachay-Swan, Amanda Runyon, and Kate E. Britt from the University of Michigan Law 
Library. I am grateful for their generous support providing library convenience during my visit to Michigan in summer 2019, during which my summer research was primarily focused on the current manuscript. As I complete the writing of the manuscript, I would also like to thank editor Ms Yongling Lam and the editorial team Ms Samantha Phua and Ms Payal Bharti, and production editor Ms Catherine Scarratt from Routledge, as well as project manager $\mathrm{Mr}$ Colin Morgan and copy-editor Ms Cecily Blench at Swales \& Willis, whose efficient and professional support has impressed me so much.

Last but not least, I would also like to thank my parents, my wife, and my children, whose love and tolerance give meaning to this research. Without my family's support, this book would not have been possible. I am grateful for their unconditional love and support.

Wenwei Guan

City University of Hong Kong Kowloon, Hong Kong SAR

December, 2019 
$\because$ Taylor \& Francis

Taylor \& Francis Group

http://taylorandfrancis.com 


\title{
1 International social contract on trade
}

\author{
Its force, means, and ends
}

During its evolution from the GATT to the WTO, the global trading regime has gradually extended its reign from goods to services, intellectual property rights, and dispute settlement. The coverage of the trade without discrimination principle under the trading regime has also been gradually extended beyond products to individuals in various capacities as traders, suppliers, and nationals with private rights. As an integral part of the international law legal order, the WTO is an international organization with an independent personality that has administrative, legislative, and judicial functions. With its three-in-one triune personality, the WTO operates upon member states' consent - the force - through rule-oriented institutionalization - the means - ultimately for the benefit of individuals - the ends - in the process of constitutionalization of the global trading regime. A unified jurisprudence looking at the WTO as an international social contract on trade would allow a fresh look at the force, the means, and the ends of the evolution of the global trading regime.

\subsection{History and evolution from the GATT to the WTO}

The development of the global trading regime of the World Trade Organization (WTO) can be traced back to the early multilateral efforts and practice of restoring international economic relations after World War II. In the second half of the 19th century, free trade among European countries had been essentially unfettered for a couple of decades, until World War I brought in a decline in free trade due to the shift of the political and economic environment. ${ }^{1}$ Efforts to establish a global trade regime in the inter-war period through tariff truces and MFN-based treaty networks started to fail with the rise of agricultural protectionism and the eventual outbreak of World War II. ${ }^{2}$

To complement the Bretton Woods institutions - the World Bank and the International Monetary Fund (IMF) - after World War II, the US proposed

1 WTO, World Trade Report 2017: Six Decades of Multilateral Trade Cooperation: What Have We Learnt? (Geneva: WTO, 2007), 35-39.

2 Ibid., 39-43. 


\section{International social contract on trade}

negotiations on the establishment of an international organization regulating trade. It was within this context that the United Nations (UN) called for the establishment of an international trade organization as a UN specialized agency. ${ }^{3}$ Alongside the efforts attempting to establish the International Trade Organization (ITO), consultations to reduce tariffs and regulatory frameworks resulted in the General Agreement on Tariffs and Trade in 1947 (GATT 1947), which was originally expected to be part of the envisaged ITO regime. Although ITO agreement could not reach an end, the GATT 1947 was agreed to be applied provisionally. ${ }^{4}$ While the negotiations of the ITO Charter eventually completed in 1948 in Havana, the Havana Charter, however, failed to come into force due to the US's opposition for the fear of sovereignty intrusion. Although the GATT 1947 lacked an organizational framework, contracting parties turned it into a de facto organization and successive trade talks continued until eventually the Uruguay Round established the WTO in 1995. As the final result of the Uruguay Round, the WTO replaced the provisional GATT with a permanent international institution regulating global trade.

Among the various significances of the transformation of the trading regime from the GATT to the WTO, there are a couple of new developments that are important to our critical examination. First of all, the coverage and reach of the trading regime have been gradually broadened throughout the years of the evolution of global trade governance which built firmly upon GATT experience with a clear jurisprudential continuity. It is particularly worth emphasizing here that the post-war negotiation aiming at ITO as a specialized UN agency had an ambitious plan to cover not only world trade disciplines but also "rules on employment, commodity agreements, restrictive business practices, international investment, and services." Although the provisional GATT focused only on tariff reduction on trade of goods at the very beginning, the trading regime's interest in other areas of trade grew broader eventually. From 1948 to 1994, the GATT was a provisional agreement and organization for 47 years, during which the GATT held eight rounds of trade talk. The first five rounds from the first round at Geneva in 1947 to the Dillon Round at Geneva between 1960-1961 focused all on tariffs. In addition to focusing on tariffs, while the Kennedy Round (the sixth, between 1964 and 1967) covered also antidumping measures, the Tokyo Round (the seventh, between 1973 and 1979) covered also subjects of non-tariff measures and "framework" agreements. ${ }^{6}$

The eighth and last round of the GATT, the Uruguay Round between 1986-1994, eventually created the WTO. The Uruguay Round, as a round to

3 UN Economic and Social Council (UN ECOSOC), Calling of an International Conference on Trade and Employment, UN Doc. E/13 (18 February 1946).

4 Protocol of Provisional Application of the General Agreement on Tariffs and Trade, signed at Geneva on 30 October 1947, UN Treaty Series 55, 308 (1950).

5 WTO, Trading into the Future (Geneva: WTO, 2001, 2nd ed.), 9.

6 Ibid., 9. 
end all rounds, covered a much broader range of subjects than all the previous rounds, including new subjects like services, intellectual property, dispute settlement, textiles, and agriculture, etc., making it "the largest negotiation of any kind in history." 7 In terms of tariff lines, the Uruguay Round increased the tariff bound percentage of developed countries from 78 to 99 percent, of developing countries from 21 to 73 percent, and of transition economies from 73 to 98 percent. $^{8}$ As the final result of the Uruguay Round, the WTO replaced the provisional GATT with a permanent international regime, coverage of which has been extended from goods to services and intellectual property backed with a much stronger dispute settlement system, the Dispute Settlement Understanding (DSU) system.

It should nevertheless be noticed that the newborn WTO is a result of the continuity of the evolution of the global trading regime, built firmly on the provisional GATT. According to the WTO Agreement, the Secretariat and the Director-General of the WTO were designed to come from the Secretariat and Director-General of the GATT. ${ }^{9}$ Most importantly, except as otherwise provided, "the WTO shall be guided by the decisions, procedures and customary practices followed by the CONTRACTING PARTIES to GATT 1947 and the bodies established in the framework of GATT 1947." ${ }^{10}$ In its discussion of the legal effect of GATT panel reports, the WTO Appellate Body stated:

Article XVI:1 of the WTO Agreement and paragraph l(b)(iv) of the language of Annex 1A incorporating the GATT 1994 into the WTO Agreement bring the legal history and experience under the GATT 1947 into the new realm of the WTO in a way that ensures continuity and consistency in a smooth transition from the GATT 1947 system. This affirms the importance to the Members of the WTO of the experience acquired by the CONTRACTING PARTIES to the GATT 1947 - and acknowledges the continuing relevance of that experience to the new trading system served by the WTO. ${ }^{11}$

Therefore, the global trading regime from the GATT to the WTO has been a process of evolutionary growth penetrating deeper into and covering a broader range of global trade, with no interruption but rather continuity firmly built on those 47 years of GATT experience.

7 Ibid., 12-13.

8 Ibid., 6.

9 Art. XVI.2, WTO Agreement.

10 Art. XVI.1, WTO Agreement.

11 Japan - Alcoholic Beverages II, WTO Appellate Body Report, WT/DS8/AB/R (4 October 1996), 14. See also, India - Patents (US), WTO Appellate Body Report, WT/DS50/AB/R (19 December 1997), 14; EU - Poultry Meat (China), WTO Panel Report, WT/DS492/R (28 March 2017), paras. 7.24-7.26. 
Secondly, although the WTO system is a comprehensive framework with lengthy agreements and annexed schedules, there are several fundamental principles run through the whole system. According to WTO Secretariat, these principles include trade without discrimination, free trade gradually through negotiation, predictability through binding, promoting fair competition, and encouraging development and economic reform. ${ }^{12}$ The most fundamental one among these five is the principle of trade without discrimination, which includes the most-favored-nation (MFN) treatment obligation and the national treatment obligation. While the MFN treatment ensures the same "best" treatment be equally available to products from all the other members beyond border, ${ }^{13}$ the national treatment guarantees foreign imported products be treated not less favorably than local products within border. ${ }^{14}$ Therefore, the trade without discrimination principle secures equal treatment for products in trade, within or beyond national borders, i.e. goods in the entire global market among all WTO Members.

The reading of the trade without discrimination principle should not be isolated from the operation of the subsidies and countervailing measures (SCM) and antidumping regimes. Negotiated in the Tokyo Round, the SCM Agreement builds on the Agreement on Interpretation and Application of Article VI, XVI, and XXIII of GATT. Regulating various government's trade distorting policies, the SCM regime prohibits governments' trade distorting action of subsidizing domestic players with advantage or more favorable terms in the marketplace, making the domestic players "better off" than they would otherwise have been. Therefore, the SCM regime targets states' trade distorting subsidies. The Antidumping Agreement on the other hand provides detailed rules governing the application of the Article VI of the GATT, enabling contracting parties to take measures to prohibit foreign companies' predatory dumping behaviors. The antidumping regime therefore regulates trade distorting effects of companies' predatory pricing behaviors. Together with the trade without discrimination's application to ensure equal treatment within and beyond borders, the SCM and antidumping regimes cover both government and companies' market distortion behaviors. Therefore, any trade distorting actions, either within or beyond borders, be it governmental or private, are all covered and regulated to refrain from obstructing fair trade.

Moreover, the coverage of the trade without discrimination principle has been gradually extended beyond products to individuals in various capacities as suppliers, exporters, and nationals with private rights. It is important to know that the MFN and national treatments covered only products in GATT 1947 as later incorporated into the WTO as GATT 1994. According to GATT 1994, any favorite treatment granted by a WTO member "to any product originating in or

12 WTO, Trading into the Future, 5-7.

13 Art. I, GATT 1994, Art. II, GATS Agreement, and Art. 4, TRIPS Agreement.

14 Art. III, GATT 1994, Art. XVII, GATS Agreement, and Art. 3, TRIPS Agreement. 
destined for any other country shall be accorded immediately and unconditionally to the like product originating in or destined for the territories of all other contracting parties." 15 As the national treatment requires, "[ $\mathrm{t}]$ he products of the territory of any contracting party imported into the territory of any other contracting party shall be accorded treatment no less favourable than that accorded to like products of national origin." 16

The principle's coverage, however, has gone beyond products to cover individuals in GATS in the capacity of "services and service suppliers," as "nationals" in TRIPS, as well as in the capacity of "exporters affected" under the Preshipment Inspection Agreement, and "suppliers" in the Agreement on Technical Barriers to Trade. Under the TRIPS Agreement for example,

Each Member shall accord to the nationals of other Members treatment no less favourable than that it accords to its own nationals with regard to the protection of intellectual property, subject to the exceptions already provided in, respectively, the Paris Convention (1967), the Berne Convention (1971), the Rome Convention or the Treaty on Intellectual Property in Respect of Integrated Circuits. ${ }^{17}$

With regard to the protection of intellectual property, any advantage, favor, privilege or immunity granted by a member to the nationals of any other country shall be accorded immediately and unconditionally to the nationals of all other members. ${ }^{18}$

Under the TRIPS Agreement, "the nationals of other Members" means "those natural or legal persons that would meet the criteria for eligibility for protection provided for" in relevant WIPO treaties. ${ }^{19}$ Going beyond GATT, GATS, and TRIPS, moreover, the trade without discrimination principle also covers individuals beyond goods in WTO Plurilateral Trade Agreements. Under the Government Procurement Agreement, for example, in relation to all laws and practices covered, "each Party shall provide immediately and unconditionally to the products, services and suppliers of other Parties offering products or services of the Parties, treatment no less favourable" than that accorded to domestic and any other party's products, services, and suppliers. ${ }^{20}$

Therefore, the historical development from GATT's provisional operation to the WTO as a permanent regime has been a continuous evolution of the global trade governance with a clear constitutional continuity. Within this continuous constitutional evolution of the trading regime there is a clear path of broadening

15 Art. I.1, GATT 1994.

16 Art. III.4, GATT 1994.

17 Art. 3.1, TRIPS Agreement. Emphasis added.

18 Art. 4, TRIPS Agreement. Emphasis added.

19 Art. 1.3, TRIPS Agreement.

20 Art. III.1, Government Procurement Agreement. 
the regulatory coverage from trade in goods to services and intellectual property rights, and to the facilitation of security and predictability through a dispute settlement mechanism. Alongside the process of constitutionalism of global trade, the broadening of regulatory impact has seen a tendency of expanding equal treatment beyond products to individuals in various capacities. What then is the nature of the dynamics between the WTO, states, and individuals in international law?

\subsection{States, the WTO, and the individuals in international law}

\subsubsection{WTO and the primacy of states}

The relation of GATT/WTO to public international law has, of course, long been one of the fundamental issues of concern, yet was only somewhat "clarified" in the more recent stages of development in the process of the constitutionalism of the global trading regime. In GATT times, there were debates as to whether GATT was a separate legal regime from public international law and thus had an independent jurisprudence and legal structure of its own. Or as McRae described, there was a contrast between a "tradition continued" model, viewing the two as having no particular implications for each other, and a "new frontier" model, "viewing the WTO within the mainstream of international law" and arguing that the WTO was an important part to be integrated into public international law. ${ }^{21}$ According to Jackson, it was, however, generally confirmed that "there are relatively numerous examples throughout the history of GATT that would oppose the 'separate regime' theory." 22 In particular in cases close to the end of the GATT where the GATT panel discussed the issue of whether general international law was relevant to GATT law, the application of general customary international law - the Vienna Convention on the Law of Treaties 1969 (1969 VCLT) in particular - was confirmed. ${ }^{23}$

The WTO framework, unfortunately, does not explicitly clarify the relation between the WTO regime and public international law. However, the Understanding on Rules and Procedures Governing the Settlement of Disputes (Dispute Settlement Understanding, DSU) clearly states that, central to WTO

21 Donald M. McRae, "The WTO in International Law: Tradition Continued or New Frontier?" 3 Journal of International Economic Law (2000), 27-30.

22 John H. Jackson, Sovereignty, the WTO and Changing Fundamentals of International Law (Cambridge: Cambridge University Press, 2006), 164-165. See also, Joost Pauwelyn, "The Role of Public International Law in the WTO: How Far Can We Go?" 95 American Journal of International Law (2001), 538-540.

23 US - Tuna II, adopted GATT Panel Report, DS/29/R (16 June 1994), paras. 5.19-5.20; EC - Cotton Yarn, adopted GATT Panel Report, ADP/137 (30 October 1995), para. 541. See discussion at Jackson, Sovereignty, the WTO and Changing Fundamentals of International Law, 165-166. 
dispute settlement system's role in "providing security and predictability to the multilateral trading system," WTO covered agreements are to be clarified "in accordance with customary rules of interpretation of public international law." 24 This, of course, is not necessarily limited to rules of treaty interpretation only; as the WTO Panel in Korea - Government Procurement suggested, there is "no basis here for an a contrario implication that rules of international law other than rules of interpretation do not apply." 25 The Panel indeed stated that "the relationship of the WTO Agreements to customary international law is broader" than the requirement of Article 3.2 of the DSU to interpret WTO provisions in accordance with customary rules of interpretation of public international law. According to the WTO Panel,

Customary international law applies generally to the economic relations between the WTO Members. Such international law applies to the extent that the WTO treaty agreements do not "contract out" from it. ... [T]o the extent there is no conflict or inconsistency, or an expression in a covered WTO agreement that implies differently ... the customary rules of international law apply to the WTO treaties and to the process of treaty formation under the WTO. ${ }^{26}$

The WTO framework thus forms an integral part of the public international law legal order. Just as the WTO Appellate Body stated clearly in US - Gasoline, the WTO covered agreements are "not to be read in clinical isolation from public international law." 27 Pauwelyn, therefore, argued that "both the WTO treaty and WTO dispute settlement are integral parts of public international law," and the interaction between international law and WTO law is a "continuing process of cross-fertilization" instead of one-sided. ${ }^{28}$

As an integral part of the legal order, the WTO is an international organization with legal personality under public international law. According to the WTO Agreement, the WTO "shall have legal personality, and shall be accorded by each of its Members such legal capacity as may be necessary for the exercise of its functions." ${ }^{29}$ WTO's power then comes from member states' attribution and is distinct from member states' power. On the one hand, the WTO as a sovereign creation to meet cooperation needs reflects a tension between two poles: "state sovereignty and the concept of function," in which "the finality of

24 Art. 3.2, DSU Agreement.

25 Korea-Government Procurement, WTO Panel Report, WT/DS163/R (1 May 2000), footnote 753 .

26 Ibid., para. 7.96.

27 US - Gasoline, WTO Appellate Body Report, WT/DS2/AB/R (29 April 1996), 17.

28 Joost Pauwelyn, "The Role of Public International Law in the WTO: How Far Can We Go?" 95 American Journal of International Law (2001), 577-578.

29 Art. VIII.1, WTO Agreement. 


\section{International social contract on trade}

the state is integral (finalité intégrée), whereas the finality of international organizations is functional (finalité fonctionnelle)." ${ }^{30}$ As ICJ Judge Gros put it,

[i]n the absence of a "super-State", each international organization has only the competence which has been conferred on it by the States which founded it, and its powers are strictly limited to whatever is necessary to perform the functions which its constitutive charter has defined. ${ }^{31}$

It therefore remains a rule of thumb that, "while states are free to act as long as this is in accordance with international law," international organizations like WTO "are competent to act only as far as powers have been attributed to them by the member states." 32 On the other hand, within its competency, the WTO's power is distinct from that of the member states, which means the WTO has a soul of its own. Indeed, according to Alvarez, any institution

once established, acquires a life of its own, independent of the elements which have given birth to it, and it must develop, not in accordance with the views of those who created it, but in accordance with the requirements of international life. ${ }^{33}$

Within the trading regime, WTO's functions have been set, intentionally or unintentionally, in a separation of powers model similar to the domestic legal system, which has administrative, legislative, and judicial functions. Accordingly, the WTO has an administrative function "facilitat[ing] the implementation, administration and operation, and further the objectives" of the WTO (Art. III.1), a legislative function in "provid[ing] the forum for negotiations among its Members concerning their multilateral trade relations" under the WTO (Art. III.2), and a judicial function of administering the DSU framework (Art. III.3). For example, within the WTO framework, members should only seek the redress of a WTO violation through resorting to DSU rules and procedures, and thus shall make no determination of a WTO violation except through recourse to the dispute settlement in accordance with the DSU rules and procedures. ${ }^{34}$ As a WTO Panel pointed out, "[i]t is for the WTO through the DSU process - not for an individual WTO Member - to determine that a WTO inconsistency has occurred." 35 Moreover, according to the Panel, WTO

30 Henry G. Schermers and Niels. M. Blokker, International Institutional Law (The Hague: Martinus Nijhoff Publishers, 2011, 5th ed.), 18.

31 ICJ, Interpretation of the Agreement of 25 March 1951 between the WHO and Egypt, Advisory Opinion, Separate Opinion of Judge Gros, ICJ Reports 1980, 103.

32 Schermers and Blokker, International Institutional Law, 157.

33 ICJ, Admission of a State to the United Nations (Charter, Art. 4), Individual Opinion by M. Alvarez, ICJ Reports 1948, 68.

34 Arts. 23,2, 23.2(a), DSU Agreement.

35 US - Section 301 Trade Act, WTO Panel Report, DS/152/R (22 December 1999), para. 7.38. 
"prohibits specific instances of unilateral conduct by WTO Members when they seek redress for WTO inconsistencies in any given dispute." ${ }^{36}$ With the administrative, legislative, and judicial functions, the WTO has an independent soul of its own associated with its triune personality built on the attribution from its member states.

Being an integral part of the public international law order with its independent legal personality, however, does not change the fact that the WTO operates on sovereign consent. While the GATT history suggests a "strong tendency" of evolving in a rule oriented direction, Jaskson argued, there is an inherent "tension between the role of the nation-state and the need for international institutions to facilitate cooperative mechanisms" to enhance the efficiency and justice of the increasingly globalized market. ${ }^{37}$ Similarly, McRae argued, there is a tension "between claims to state authority and claims to international control" in the dispute settlement framework, and the WTO is best understood as "a regime based on the fundamental assumptions of a liberal trade order, but working within a framework of a sovereignty-based system." 38 In the arena in which the WTO is operating, state is the primary subject of public international law, and "it is states and organizations which represent the normal types of legal person on the international law plane." 39 As Jessup suggested,

The inescapable fact is that the world is today organized on the basis of the coexistence of states, and that fundamental changes will take place only through state action, whether affirmative or negative. ... It is true to say that states themselves operate by virtue of the will of individuals and that the individual is thus the ultimate source of authority. Yet so firmly rooted is the international state system that we are accustomed to think in terms of the state itself as the ultimate authority and sole actor. ${ }^{40}$

The statement of state primacy in international law is parallel to individual's status in public international law. As Crawford argued, though "it is no longer possible to deny that individuals may have rights and duties in international law; but what rights and duties they do have depends ... not on any notion of natural personality operating with the legal system."41 Therefore, to classify the individuals as a "subject" of international law "is unhelpful," even if individuals might have rights inuitu personae that can be vindicated in particular contexts in

36 Ibid., para. 7.39 .

37 John H. Jackson, “International Economic Law in Times That Are Interesting," 3 Journal of International Economic Law (2000), 9.

38 McRae, "The WTO in International Law," 41.

39 James Crawford, Brownlie's Principles of Public International Law (Oxford: Oxford University Press, 2012, 8th ed.), 116. Emphasis original.

40 Philip C. Jessup, A Modern Law of Nations: An Introduction (New York: The MacMillan Company, 1948), 17-18.

41 Crawford, Browlie's Principles of Public International Law, 17. 
the field of human rights and investment protection. ${ }^{42}$ International law provides no means for the enforcement of the individual responsibilities and rights dealt with in the provisions of those human right instruments. ${ }^{43}$ Indeed, although the WTO's operation is ultimately for the benefits of the individuals, its relation with individuals remains "indirect." 44

\subsubsection{The sanctity of WTO obligations}

As a constitutional principle rooted in natural law confirming the state autonomy principle that "an autonomous State has power to consent, to bind itself so as to bind another," pacta sunt servanda doctrine is fundamental to public international law. ${ }^{45}$ The doctrine was incorporated in the UN Charter to oblige members to "fulfil in good faith the obligations assumed by them" in accordance with the UN Charter for "ensur[ing] to all of them the rights and benefits resulting from [UN] membership." 46 This sanctity of treaty obligations has further been clearly specified in the 1969 VCLT. According to the VCLT, "every treaty in force is binding upon the parties to it and must be performed by them in good faith," and domestic law is no good defense for treaty noncompliance. ${ }^{47}$ Moreover, this principle is also the most important one in international economic law and the foundation of international trade and finance. According to Henkin,

The most important principle of international economic law, as of all international law, was and is pacta sunt servanda - agreements are to be kept. The sanctity of undertakings, in treaties as well as in commercial contracts, between Governments, between Governments and foreign nationals, or between nationals of different countries - has been the foundation of international trade and finance. ${ }^{48}$

Indeed, the pacta sunt servanda doctrine as the foundation of international law has also clearly been incorporated in the GATT/WTO framework with rather similar language. Under the GATT framework, for example, each contracting party is under the obligation to take all "reasonable measures" possible to ensure its regional and local governments and authorities' observance of the GATT provisions. ${ }^{49}$ More broadly, it is incorporated in the WTO Agreement:

42 Ibid., 121.

43 Ibid.

44 See discussion infra, 1.2.3, 1.3.1, and 1.3.2.

45 Louis Henkin, International Law: Politics and Values (The Hague: Martinus Nijhoff Publishers, 1995), 28.

46 Art. 2.2, the UN Charter.

47 Arts. 26 and 27, 1969 VCLT.

48 Henkin, International Law: Politics and Values, 149.

49 Art. 24.12, GATT 1994. 
Each Member shall ensure the conformity of its laws, regulations and administrative procedures with its obligations as provided in the annexed Agreements. ${ }^{50}$

Accordingly, WTO members are required to "ensure the conformity" of their laws, regulations, and administrative procedures with the WTO obligations. The "conformity" requirement covers both future legislation and actions, as well as existing laws, regulations, and administrative procedures. In discussion of the SPS Agreement compliance issue in a dispute, a WTO Panel states:

We finally note that according to Article XVI:4 of the WTO Agreement, each Member "shall ensure the conformity of its laws, regulations and administrative procedures with its obligations as provided in the annexed Agreements [including the SPS Agreement]". This provision confirms that measures which already existed as of the date of entry into force of the SPS Agreement also need to be consistent with the requirements imposed by that Agreement. ${ }^{51}$

Therefore, the conformity obligation under the WTO to a certain extent expects WTO members to review existing legal and regulatory frameworks and amend them in order to conform with the new international treaty obligations when and wherever is needed. Some of the transitional arrangements in WTO covered agreements were therefore instituted for the purpose of allowing the members a sufficient period of time to comply with WTO rules. ${ }^{52}$ The pacta sunt servanda doctrine thus reflects the rigidity of the WTO framework, as any noncompliance or inconsistency will be considered as a WTO violation. According to the DSU, where an action breaches the rules of a WTO covered agreement, a WTO violation, i.e. a case of nullification or impairment, will be assumed. ${ }^{53}$ This indeed reflects the rigidity of the WTO norms.

The rigidity of the WTO obligations, however, has not changed the fact that members remain sovereign, thus free, after they accede to the multilateral trading framework. Under public international law in general, the manner in which international law applies within a state is a matter governed by the law of that state. As pointed out in Oppenheim's International Law:

From the standpoint of international law states are generally free as to the manner in which, domestically, they put themselves in the position to meet

50 Art. 16.4, WTO Agreement.

51 EC-Hormones (US), WTO Panel Report, WT/DS26/R, para. 8.27. See also, EC-Hormones, WTO Appellate Body Report, WT/DS26/AB/R, para. 128; US-1916 Act (Japan), WTO Panel Report, WT/DS162/R, para. 6.287; US-1916 Act (EC), WT/DS136/R, para. 6.223.

52 See e.g. Arts. 65 et sep., TRIPS Agreement; Arts. 28 et sep., SCM Agreement.

53 Art. 3.8, DSU Agreement. 
their international obligations; the choice between the direct reception and application of international law, or its transformation into national law by way of statute, is a matter of indifference, as is the choice between the various forms of legislation, common law, or administrative action as the means for giving effect to international obligations. These are matters for each state to determine for itself according to its own constitutional practices. ${ }^{54}$

Therefore, regarding TRIPS compliance, for example, while all TRIPS Members are required to "give effect to" the TRIPS provisions, they nevertheless remain free to choose whatever appropriate way of implementation:

Members may, but shall not be obliged to, implement in their law more extensive protection than is required by this Agreement, provided that such protection does not contravene the provisions of this Agreement. Members shall be free to determine the appropriate method of implementing the provisions of this Agreement within their own legal system and practice. ${ }^{55}$

The TRIPS Agreement further clarifies that TRIPS

does not create any obligation to put in place a judicial system for the enforcement of intellectual property rights distinct from that for the enforcement of law in general, nor does it affect the capacity of Members to enforce their law in general,

and creates no obligation with respect to "the enforcement of law in general." 56

Indeed, GATT/WTO obligation is an "obligation of result" rather than an “obligation of means." Under the DSU, a member may recourse to the DSU proceeding when any of their benefits under the WTO Agreements are "being impaired" by another member's measures to the effect of "[a] nullification or impairment of benefits under the covered agreements or an impediment to the attainment of any objective of the covered agreements." 57 The wording "being impaired" denotes a factual happening rather than a simple possibility of violation, nor a limitation on the manner fulfilling WTO obligations. It has long been an established GATT jurisprudence that members can challenge legislation independently from specific application instances, yet only non-discretionary or mandatory legislation that mandates a violation of GATT obligation can be found to be in violation of WTO obligations. In EEC - Regulation on Imports of Parts and Components, Japan challenged EEC's measures taken under its anti-

54 Robert Jennings and Arthur Watts, Oppenheim's International Law (London: Longman Group UK Ltd., 1992, 9th ed., vol. I), 82-83.

55 Art. 1.1, TRIPS Agreement.

56 Art. 41.5, TRIPS Agreement.

57 Arts. 3.3, 23.1, DSU Agreement. 
circumvention provision to impose tax on products made in the EEC by companies related to Japanese companies. The measures taken by EEC were found in violation of EEC's obligations under GATT. However, Japan's suggestion requesting the EEC not only revoke the measures taken but also take down the provision concerned was rejected by the Panel. According to the Panel,

the mere existence of the anti-circumvention provision in the EEC's antidumping Regulation is not inconsistent with the EEC's obligations under the General Agreement. ... [T] he EEC would meet its obligations under the General Agreement if it were to cease to apply the provision in respect of contracting parties. ${ }^{58}$

This is to leave room for governments to deviate from their GATT obligations in relation to third non-GATT governments. ${ }^{59}$

Moreover, WTO members have the ultimate freedom of withdrawing from the WTO. According to the WTO Agreement, any WTO member may withdraw from the WTO framework freely without condition with six months' written notice of withdrawal to the Director-General of the WTO. ${ }^{60}$ It should be noticed that the GATT 1947 system also provided withdrawal provisions for specific situations in which impairment of reciprocal concessions resulted in the disadvantage of a Contracting Party. ${ }^{61}$ The binding force of the WTO regime, therefore, is paradoxical in nature. States are autonomous and free through consent to join the WTO and to be bound by its rules, yet ultimately remain free to withdraw from the WTO - under public international law.

\subsubsection{WTO's “indirect impact on individuals"}

As an international organization operating in the arena where states have primacy, a tension is created between international law and domestic law that bears fundamental importance to individuals' status in international law, an issue of concern in relation to the monism and dualism dichotomy debate. The relationship between international law and domestic law, according to Henkin, was once "considered in the light of two polar conceptions [between monism and dualism]." 62 While monists insisted that "the legal system of every state is a single system consisting of international law and the state's own domestic law, with international law supreme," dualists argued that international law and

58 EEC - Regulation on Imports of Parts and Components, O J. L/6657 - 37S/132, adopted GATT Panel Report (16 May 1990), para. 5.26.

59 However, according to the WTO Panel in US - Section 301 Trade Act (para. 7.97), even if legislation is not mandatory but discretionary in nature, it was prima facie inconsistent with Article 23 of the DSU.

60 Art. XV, WTO Agreement.

61 Arts. XVIII.12(e), XXIII.2, and XXX.2, GATT 1947.

62 Henkin, International Law: Politics and Values, 64. 
domestic law are distinct legal systems and international law operates wholly between states and "does not penetrate a state's internal legal system." ${ }^{63}$ Some prominent international law scholars, Lauterpacht for example, are forceful advocates of a version of monism emphasizing that "individuals are the ultimate subjects of international law, representing both the justification and moral limit of the legal order." ${ }^{64}$ However, Henkin pointed out, the differences between the two were theoretical and conceptual only, and "appear not to have inspired significant differences between states in their application of international law." "The international system today," according to Henkin, "is essentially dualist in principle but it has slowly moved a few steps towards monism in practice." 60

Moreover, Henkin pointed out, the statement that "only states are subjects of international law" is not true, or no longer true if it ever was. ${ }^{67}$ While "law is made by states," according to Henkin, states accordingly have also "created (or recognized) other entities, and have given them status, powers, rights, responsibilities, and remedies, within the international system." 68 While the nationality of companies is "a fiction upon a fiction, deriving from the larger fiction of state sovereignty," the wide international acceptance of a market economy might bring a change, in which the company may prove to be the essential unit of the world economy and to be considered as "a new entity in the international system." $" 69$

The WTO, as an international organization established by and operated among governments, is nevertheless closely related to individuals. A WTO Panel's discussion on GATT/WTO's relevance to individuals shed some light on the issue. According to a WTO Panel, one of WTO's objects and purposes considered to be relevant to the strengthening of the multilateral system is the "the creation of market conditions conducive to individual economic activity in national and global markets and to the provision of a secure and predictable multilateral trading system." ${ }^{\text {70 }}$ As to the direct effect issue, the Panel agreed that neither the GATT nor the WTO has so far been considered as a legal regime producing direct effect, as "the GATT/WTO did not create a new legal order the subjects of which comprise both contracting parties or Members and their nationals." 71 Yet the Panel also emphasized that,

However, it would be entirely wrong to consider that the position of individuals is of no relevance to the GATT/WTO legal matrix. Many of the

63 Ibid., 64-65.

64 Crawford, Browlie's Principles of Public International Law, 48.

65 Henkin, International Law: Politics and Values, 65.

66 Ibid., 66.

67 Ibid., 16-17.

68 Ibid., 17.

69 Ibid., 24.

70 US - Section 301 Trade Act, WT/DS152/R, para. 7.71.

71 Ibid., para. 7.72 . 
benefits to Members which are meant to flow as a result of the acceptance of various disciplines under the GATT/WTO depend on the activity of individual economic operators in the national and global market places. The purpose of many of these disciplines, indeed one of the primary objects of the GATT/WTO as a whole, is to produce certain market conditions which would allow this individual activity to flourish. ${ }^{72}$

Due to GATT/WTO regime's "indirect impact on individuals," the Panel pointed out, a domestic legislation, "independent from its application in specific instances," may constitute a GATT/WTO violation, though it might not raise state responsibility under public international law. ${ }^{73}$ As different from treaties concern only the relations between states, a treaty's benefits depend partially on individuals' activity, a simple legislation inconsistency itself, even if without action, may constitute a breach due to its "appreciable 'chilling effect' on the economic activities of individuals." 74 The GATT/WTO system, according to the Panel, therefore, "is, per force, composed not only of States but also, indeed mostly, of individual economic operators. The lack of security and predictability affects mostly these individual operators." 75

Indeed, to ensure the security and predictability of issues that can affect individual operators, the WTO regime provides various judicial remedy provisions in the annexed agreements. In GATT 1947 for example, as to "publication and administration of trade regulations," members are required to publish "laws, regulations, judicial decisions and administrative rulings of general application" to "enable governments and traders to become acquainted with them." According to GATT 1947, moreover:

Each contracting party shall maintain, or institute as soon as practicable, judicial, arbitral or administrative tribunals or procedures for the purpose, inter alia, of the prompt review and correction of administrative action relating to customs matters. Such tribunals or procedures shall be independent of the agencies entrusted with administrative enforcement and their decisions shall be implemented by, and shall govern the practice of, such agencies unless an appeal is lodged with a court or tribunal of superior jurisdiction within the time prescribed for appeals to be lodged by importers ... ${ }^{77}$

It is important to note that the non-discrimination treatment requirement, including the MFN and national treatment under GATT 1947, cover only

72 Ibid., para. 7.73 .

73 Ibid., paras. 7.80-7.81.

74 Ibid., para. 7.81 .

75 Ibid., para. 7.76.

76 Art. X.1, GATT 1947. Emphasis added.

77 Art. X.3.(b), GATT 1947. Emphasis added. 
products rather than individuals. ${ }^{78}$ The reference here to "traders" in general and to "importers" in relation to judicial remedies through judicial, arbitral or administrative tribunals or procedures domestically, are laid down as governments' obligations to "traders" and "importers." This indeed reveals the truth that the bearers of the international trade relation ultimately are individuals. Most importantly, this kind of judicial review remedy provision is spread out over many annexed agreements, including Sanitary and Phytosanitary Measures Agreement, Antidumping Agreement, SCM Agreement, Customs Valuation Agreement, Preshipment Inspection Agreement, Rules of Origin Agreement, GATS, TRIPS, and Government Procurement Agreement. ${ }^{79}$ These various provisions laid down obligations on members to provide individuals in various capacities judicial review remedies via "judicial, arbitral or administrative tribunals or procedures" independent from administrative enforcement agencies. To some extent, the GATT/WTO indeed is all about the individuals. According to the WTO Agreement, WTO members recognize that:

[WTO members'] relations in the field of trade and economic endeavour should be conducted with a view to raising standards of living, ensuring full employment and a large and steadily growing volume of real income and effective demand, and expanding the production of and trade in goods and services, while allowing for the optimal use of the world's resources in accordance with the objective of sustainable development, seeking both to protect and preserve the environment and to enhance the means for doing so in a manner consistent with their respective needs and concerns at different levels of economic development. ${ }^{80}$

Indeed, the WTO's objectives of improving the living standards, employment, and income, even the expansion of trade in goods and services and optimal use of the resources and environment, are ultimately for the benefit of individuals. These objectives reconcile very well with that of the UN Charter, where the facilitation of security, human rights and dignity, and justice is for the purpose of "promot[ing] social progress and better standards of life in larger freedom." 81 Moreover, the means to achieve WTO objectives in relation to living standards, employment, and income, according to the WTO Agreement, is to establish "reciprocal and mutually advantageous arrangements" that lead to the substantial reduction of trade barriers and the elimination of discriminatory

78 Arts. I and III, GATT 1947.

79 See Art. 1, Annex C, Sanitary and Phytosanitary Measures Agreement; Art. 11, Antidumping Agreement; Art. 23, SCM Agreement; Art. 11, Customs Valuation Agreement; Art. 4, Preshipment Inspection Agreement; Art. 2 and Art.3.(f), Annex 2, Rules of Origin Agreement; Art. 6.2, GATS; Arts. 32, 41.1, 41.2, 41.4, and 49, TRIPS; and Arts. 20.1 and 20.2, Government Procurement Agreement.

80 First Recital, Preamble, the WTO Agreement.

81 Preamble, the UN Charter. 
treatment. $^{82}$ Furthermore, the purpose of improving living standards, employment, and income, as well as optimal use of resources and environment through "reciprocal and mutually advantageous arrangements," is "to develop an integrated, more viable and durable multilateral trading system." 83 Therefore, the constitutional evolution of the WTO as an integrated multilateral trading system is for the purpose of improving individuals' living standards, employment, and income, as well as optimal use of resources and environment through reduction of trade barriers and the elimination of discriminatory treatment. Reading the recitals of the preamble to the WTO Agreement organically as a whole, the GATT/WTO global trading regime is in fact all about the welfare of individuals.

\subsection{WTO as an international social contract on trade}

\subsubsection{Theories of the nature of WTO constitutionalism connected}

Operating in the global arena where states hold primacy, WTO as an international organization with three functions (legislative, administrative, and adjudicative) in one triune personality raises multiple possibilities of the categorization of its nature. The description of the regime by one of the most prominent GATT/WTO scholars, Robert E. Hudec, offers a unique perspective into the issue of the nature of the GATT/WTO, which reflects to certain extent a crucial part of the triune personality of the GATT/WTO. Hudec characterized international trade law as something between law and politics. He argued that the GATT/WTO legal system is a "diplomat's jurisprudence," and that its law "has been designed and operated as an instrument of diplomacy," in which the GATT/WTO diplomats "reconcile, on their own terms, the regulatory objectives of a conventional legal system with the turbulent realities of international trade affairs." 84 For Hudec, GATT/WTO law is designed to soften conventional regulatory pressure to a "looser sort of compulsion" applied by diplomats in a style of "sophisticated and often artistic use of ambiguity" to deal with realistic concerns "not necessarily bounded by the lawyer's rather clear cut criteria of what is and is not 'legal'." 85 Thus Hudec argued that the main point on which international trade law differs from a domestic legal system is "the overriding concern for 'flexibility' - the insistence that the law's coercive pressures

82 Third Recital, Preamble, the WTO Agreement.

83 Fourth Recital, Preamble, the WTO Agreement.

84 Robert E. Hudec, Essays on the Nature of International Trade Law (London: Cameron May, 1999), 17, 75 .

85 Ibid., 33-35. He analyzed how dispute settlement process in GATT/WTO is different from conventional judicial decision-making. He aruged that "the Panel decision is a far less static instrument than the conventional court decision. Rather than being a final resolution of the legal issue, the Panel decision is simply the first stage in larger decision-making process that involves the whole community." Ibid., 66. 
be applied in a controlled fashion which allows room for manoeuvre at every stage of the process," moreover, this flexibility gives the GATT/WTO "a capacity for creative development," some "possibility of growth." 86 According to Hudec, although the tentative nature of GATT/WTO texts is meant to be used as "binding and dispositive authority," they also give the community "greater claim to authority than would be the case of ad hoc response," in which there is always the "possibility of growth." ${ }^{87}$ How would this "possibility of growth" be realized? According to Hudec, this "possibility of growth" is realized through justifying disobedience. He argued that "there are situations in which disobedience can be justified, as a matter of policy, in terms of strengthening support for the legal system in question." ${ }^{88}$ The state primacy certainly will be the ultimate justification of the deviation from or non-compliance of the WTO treaty obligations, a paradoxical force that supports and at the same time challenges the operations of the WTO.

Another prominent GATT/WTO scholar, John H. Jackson, recognized GATT/WTO's inherent tension between power oriented vs. rule oriented philosophy, in particular in the early era of the trading regime. Jackson's recognition of the power oriented approach's impact on the inherent tension confirms, at least partially, Hudec's categorization of GATT/WTO's diplomat's jurisprudence feature. According to Jackson, the overall characterization of the history of "constitutional evolution" from the provisional GATT application to the WTO framework is one that "the institutions have developed from bottom up, rather than top down." 89 Within this process of constitutionalism, according to Jackson, there is an inherent tension between power oriented and rule oriented perspectives ever since the start of the GATT framework:

So at the very start [of the GATT] there was a tension about the goals of this [dispute settlement] procedure. On the one hand, there were those who felt it was simply an extension of the diplomatic process, what I describe as the "power oriented" process. Basically the hope of this approach was that the procedure would help governments settle their differences. On the other hand, in a "rule oriented" process the idea is to achieve

86 Ibid., $75-76$.

87 Ibid., 35. He went on to argue that "[a]s the consensus on one point or another becomes more positive over time, these ambiguous sources of authority can provide the formal basis for absorbing such developments into a regular legal framework." Ibid.

88 Ibid., 209. He described five general guidelines for justifiable disobedience: (1) is "consistent with the general objectives of the Agreement"; $(2)$ is in a good faith to "achieve the desired legal change by negotiation"; (3) is "accompanied by an offer to continue to negotiate in good faith"; (4) must be limited to that "which is necessary to achieve a negotiated legal reform of the kind required"; and (5) must "accept the consequences imposed by law for it." Ibid., 208.

89 John H. Jackson, "Fragmentation or Unification among International Institutions: The World Trade Organization," 31 International Law and Politics (1999), 823, 826. 
a result that is rule-consistent and that perhaps helps interpret and elaborate the meaning of the rules, so as to add to the longer term predictability and stability of the system. ${ }^{90}$

Jackson's constitutionalism reading of the GATT/WTO, nevertheless, emphasizes the institutional nature of the constitutional evolution. His institutional constitutionalism appears somewhat distant from Hudec's diplomat's jurisprudence, in particular in his categorization of the basic premises, basic themes, and constituent principles of the world trading system. According to Jackson, two basic premises of the global trading system are that "economic concerns have taken center stage in foreign affairs decision making," and that the international economics problem is a "problem of "managing' interdependence" which is constituted by international institutions. ${ }^{91}$ Jackson argued that the key issue of managing interdependence is the "allocation of decision-making authority at different levels of government." 92

According to Jackson, the basic theme of international trade law is the tension between "the necessity for legal rules conducive to stability and predictability, and the human need for solutions to short-term and ad hoc problems," or simply the "dilemma of rule versus discretion."93 This dilemma, along with Hudec's perception of the "possibility of growth" of the evolving international trade law, suggests that the WTO regime might just be a dynamic regulatory regime evolving with a soul of its own. Another "persistent theme" of the international trade law is the "close interaction of national and international institutions." 94 For Jackson, "the domestic and international rules and legal institutions of economic affairs are inextricably intertwined," and moreover, the world trading system is "a complex interplay of both national and international norms, institutions, and policies."95 This indeed confirms Pauwelyn's categorization of the interplay between domestic and international trade laws and institutions as a "continuing process of cross-fertilization." 96

Different from Jackson's perspective of the WTO as a constitutionalization process of an institutional order, the approach of another prominent WTO scholar, Ernst-Ulrich Petersmann, offered a third perspective on the nature of the WTO as constitutionalization of a rights-based system. ${ }^{97}$ Deeply rooted in

90 Ibid., 823, 826-827. Emphasis added.

91 John H. Jackson, The World Trading System: Law and Policy of International Economic Relations (Cambridge, MA: MIT Press, 1997, 2nd ed.), 4, 7-8.

92 Ibid., 346.

93 Ibid., 10, 29.

94 Jackson, The World Trading System, 29.

95 Ibid., 26, 341.

96 Pauwelyn, "The Role of Public International Law in the WTO," 578.

97 Deborah Z. Cass, "China and the 'Constitutionalization' of International Trade Law," in Deborah Z. Cass et al. (eds.), China and the World Trading System (Cambridge: Cambridge University Press, 2003), 42-48. 
Kantian philosophy and encouraged by the success of the European integration, Petersmann argued that "the guarantees of freedom and non-discrimination in WTO law serve human rights functions by enabling individuals to enhance their personal autonomy and welfare through peaceful cooperation across frontiers." 98 According to Petersmann, therefore,

By extending equal freedoms across frontiers and subjecting discretionary foreign policy powers to additional legal and judicial restraints ratified by domestic parliaments, the WTO rules - even if formulated in terms of rights and obligations of governments - serve "constitutional functions" for rendering human rights and the corresponding obligations of governments more effective in the trade policy area. ${ }^{99}$

As Petersmann argued, the insight of the "functional theories" has been confirmed by the success of the European integration, in which the citizen-driven market integration provides strong incentives for transforming "market freedoms" into "fundamental rights." 100 "The moral 'categorical imperative' of maximizing personal autonomy and equal liberties across frontiers," for Petersmann, "corresponds with the economic objective of maximizing consumer welfare through open markets and non-discriminatory competition."101 Moreover, beyond the issue of "moral legitimacy," there is also "[an] economic necessity for the proper functioning of economic and 'political markets' and for rendering competition 'self-enforcing' by assignment of individual freedoms, property rights and liability rules to all economic actors and scarce resources."102 Petersmann thus argued that

The time has come to recognize that human rights law offers WTO rules moral, constitutional and democratic legitimacy that may be more important for the parliamentary ratification of future WTO Agreements than the traditional economic and utilitarian justifications. ${ }^{103}$

Of course, Jackson and Petersmann's perspectives of constitutionalism, and even Hudec's categorization of the diplomat's jurisprudence, are not irreconcilable views, but rather highly interrelated. Dunoff, for example, categorized the WTO

98 Ernst-Ulrich Petersmann, "From 'Negative' to 'Positive' Integration in the WTO: time for 'mainstreaming human rights' into WTO Law?" 37.6 Common Market Law Review (2000), $1363-1382,1375$.

99 Ernst-Ulrich Petersmann, "Time for a United Nations 'Global Compact' for Integrating Human Rights into the Law of Worldwide Organizations: Lessons from European Integration," 13.3 European Journal of International Law (2002), 621-650, 644.

100 Ibid., 629.

101 Ibid., 629-630.

102 Ibid., 1376.

103 Ibid., 1377. 
constitutionalism discourse into three perspectives, namely, Jackson's “constitutionalism as institutional architecture," Petersmann's "constitutionalism as normative commitments," and Cass' “constitutionalism as judicial mediation." 104 Given that Cass depicted WTO constitutionalism through the constitutional norms generating process of the WTO as a rule-based institution, the WTO's Appellate Body in particular, ${ }^{105}$ Cass' perspective reflects the process perspective of Jackson's WTO institutional constitutionalism. While Jackson and Petersmann address the (institutional) means and the (humanitarian) ends of, Hudec explains the force, the source of the authority and political nature of the WTO constitutionalism.

\subsubsection{International social contract and WTO constitutionalism}

Whether considering the diplomatic, institutional, or constitutional characterization of the nature of the WTO, each reflects its respective part of the truth of the WTO as an intergovernmental organization with triune personality, operating ultimately for the benefit of individuals in a global arena where states hold primacy. On the one hand, Hudec's diplomat's jurisprudence captures the inner truth of the background of the state primacy within which the WTO operates and from which the WTO derives its personality and authority. The early smooth functioning of the WTO, in particular the rapid growth of the DSB case law in which 20 years of the WTO solved more disputes than 47 years of the GATT, ${ }^{106}$ might to some extent have been signaling the fading away of the diplomat's jurisprudence. The deadlock of the Doha negotiation, the dismantling of the Appellate Body appointments, and the ongoing China-US trade war, certainly indicated that the diplomat's jurisprudence is deeply rooted in the WTO. ${ }^{107}$ On the other hand, while Jackson touches the institutional structure and process - the means - of WTO's constitutional process, Petersmann captures the categorical imperative - the ends - of WTO's constitutional evolution. The complexity of the international constitutional evolution based on market economy principles gains its energy from and constructs a soul of itself for global trade.

Although Jackson's focus was on the institutional evolution of the GATT/ WTO constitutionalism, the picture of the constitutionalism Jackson presented nevertheless captures the constitutional dynamics of the means and the ends

104 Jeffrey L. Dunoff, "Constitutional Conceits: the WTO's 'Constitution' and Discipline of International Law," 17.3 European Journal of International Law (2006), 651-656.

105 Ibid., 655-656.

106 WTO, 20 Years of the WTO: A Retrospective (Geneva: WTO, 2015), 78.

107 WTO Documents, United States - Tariff Measures on Certain Goods from China III: Request for Consultation by China, WT/DS587/1 (4 September 2019). In this consultation request, China claimed that the US's overall 15 percent tariff increase on goods from China under the US's Notice of Modification of Section 301 Action dated 20 August 2019 violates its GATT 1994 commitment. 
within bounds described by the political force of state primacy in the process of the evolution of the global trading regime:

We are dealing with a process involving the global systems as we know them today, systems which, especially in recent decades, have tended to focus on market economy principles. We are dealing with the decentralized decision-making of millions and millions of entrepreneurs. So one of the goals of this system is to have a rule structure that provides a certain amount of predictability and stability, which will help shape how those millions and millions of economic decisions are and can be made. ${ }^{108}$

Therefore, while Hudec captures the force, and Jackson captures the means, Petersman captures the ends of the constitutionalism process of the WTO. As an international organization with triune personality, an all-round WTO jurisprudence should capture the force, the means, and the ends of the constitutionalism process of the global trading regime, operating on the foundation of state primacy and ultimately for individuals' benefit. However, neither is the WTO constitutionalism process a linear development, nor does it proceed without any problem. Alston, for example, suggested that Petersmann's application of Kantian philosophy of international morality to international law might not have paid enough attention to the complexity of the conceptually challenging move. ${ }^{109}$ However, what Petersmann tried to emphasize is human rights' constitutive function for welfare-creation - the ends of the WTO constitutionalism evolution as we analyzed it - and to argue for equal protection of human rights in both economic markets and political markets. ${ }^{110}$

The dynamics among the force, the means, and the ends of the evolution of the global trade, and the complexity of the WTO constitutionalism have indeed been well reflected in the controversies of the WTO constitutionalism debates in academia. As Dunoff pointed out, the WTO constitutionalism discourse, to some extent, seems to have a "self-defeating nature" and "reflects a disciplinary anxiety over international law's status and role," which suggests that the louder the references are to the constitutional discourse, the weaker is the evidence for the constitutional features we can find in the WTO. ${ }^{111}$ The invocation of constitutional discourse at the GATT/WTO in particular or in international law in general, may be a response utilizing a "rhetorical strategy" to deal with disciplinary anxiety through "invest[ing] international law with the power and

108 Jackson, "Fragmentation or Unification among International Institutions," 823-831.

109 Philip Alston, "Resisting the Merger and Acqusition of Human Rights by Trade Law: A Reply to Petersmann," 13.4 European Journal of International Law (2002), 815, 839.

110 Ernst-Ulrich Petersmann, "Taking Human Dignity, Poverty and Empowerment of Individuals More Seriously: Rejoinder to Alston," 13.4 European Journal of International Law (2002), 845-851.

111 Dunoff, "Constitutional Conceits," 647-675. 
authority that domestic constitutional structures and norms possess."112 Each of these versions of WTO constitutionalism, according to Dunoff, provides "a mechanism for withdrawing an issue from the battleground of power politics and as a vehicle for resolving otherwise politically destabilizing political disputes through reference to a meta-agreement." 113 Dunoff therefore pointed out that "the turn to constitutionalism is self-defeating because constitutionalism does not and cannot generate finality on highly contested issues; it cannot deliver on its promise to remove divisive issues from the domain of politics." 114

The discussion of WTO's "self-defeating" turn to constitutionalism, however, is of fundamental importance to our discussion at least in two ways. First of all, the "failure," if any, of the quest for the means and the ends of the WTO constitutionalism as the escape from power politics actually reflects the unfortunate truth that the power politics is inherent to the roots of the GATT/WTO. Either Jackson or Petersmann's perspective of the GATT/WTO should therefore be reconciled with, rather than distinguished from, Hudec's diplomat's jurisprudence perspective of the GATT/WTO. Secondly, power politics within the reign of the international law where states hold primacy remains the foundation of the GATT/WTO constitutionalism evolution. Therefore, as Dunoff acknowledged, variations of the WTO constitutionalism, not only were "made in the service of a larger turn away from politics," but also were presented "as a corrective or replacement for unruly and potentially destructive trade politics."115 Dialectically as well as practically, any denial of the force must at the same time be a recognition of the force of the power politics in the process of the GATT/WTO constitutionalism evolution. Both WTO constitutionalism's denial and recognition of the force of the power politics indeed bring us to international law's discussion of the " $S$ " word - sovereignty - and the nature of the WTO as an international social contract on trade. Remember it was a fear of the sovereignty intrusion that made the US, the strongest trading power, bar the negotiated ITO from coming into force.

Although elements inherent in "sovereignty" might have been considered as fictions or fictions upon fictions, Henkin argued, independence, equality, autonomy, and integrity, etc., remain essential characteristics and indicia of modern statehood. ${ }^{116}$ As an implication of state autonomy, state consent remains the foundation of international law and that international law is binding on a state only by its consent remains "an axiom of the political system."117 Accordingly, state autonomy suggests that a state has "will," "the power to consent, to enter into relations," through which "States have in effect created the international

112 Ibid., 649.

113 Ibid., 662.

114 Ibid., 665.

115 Ibid., 664-665.

116 Henkin, International Law: Politics and Values, 10.

117 Ibid., 27. 


\section{International social contract on trade}

political system, by a kind of international 'social contract'."118 Therefore, "the international system has in its basic law a law of contract, known as the law of treaties." 119 As Henkin indicated, the state system indeed "is established by the consent of states, in effect by an inter-state social contract," and virtually all law "is the result of contract" or rooted in consent (contract) of states. ${ }^{120}$ The WTO Appellate Body's discussion in Japan - Alcoholic Beverage II elaborated this social contract nature well:

The WTO Agreement is a treaty - the international equivalent of a contract. It is self-evident that in an exercise of their sovereignty, and in pursuit of their own respective national interests, the Members of the WTO have made a bargain. In exchange for the benefits they expect to derive as Members of the WTO, they have agreed to exercise their sovereignty according to the commitments they have made in the WTO Agreement. ${ }^{121}$

Taking the WTO regime as a social contract on trade has mixed implications for our analysis. On the one hand, taking the WTO framework as a social contract among sovereign states for sure explains well the foundation of the global trading framework, yet at the same time plants an inherent "sovereign paradox" in it. According to Schermers and Blokker, the tension between "the formal independence (sovereignty) of states and their actual interdependence" has always been a "classic theme" of the international legal system. ${ }^{122}$ This classic theme, accordingly, produces "the paradox that, in order to exercise their functions and to remain as independent as possible, states are forced to cooperate due to the unavoidable reality of interdependence and globalization." 123 This "paradox" derived from the classic theme is indeed deeply rooted in the social contract theory. The Rousseauian construction of the social contract starts from the moment when we as free individuals are looking for a collective association under which each individual, "while uniting himself with the others, obeys no one but himself, and remains as free as before."124 The solution Rousseau found is a social contract, a paradoxical imagination in which people are free to engage in a contract in order to be bound, and to be the legislators and subjects of the social contract at the same time. ${ }^{125}$

118 Ibid., 11.

119 Ibid., 102.

120 Ibid., 103.

121 Japan - Alcoholic Beverages II, WTO Appellate Body Report, WT/DS8/AB/R (4 October 1996), 15.

122 Schermers and Blokker, International Institutional Law, 2.

123 Ibid.

124 Jean-Jacques Rousseau, The Social Contract (London: Penguin, 1968), 60.

125 For the critique of the Rousseauian contractarian paradox, see discussion infra 2.4 "Consensus's Contractarian Deficits and WTO Legitimacy." 
On the other hand, the emphasis of the sovereign independence dialectically necessitates the interdependence among sovereign states in order to recognize and confirm each other's autonomy and to control external influences. This indeed was elaborated well in the UN's Agenda for Peace:

The foundation-stone of this work [of the United Nations] is and must remain the State. Respect for its fundamental sovereignty and integrity are crucial to any common international progress. The time of absolute and exclusive sovereignty, however, has passed; its theory was never matched by reality. It is the task of leaders of States today to understand this and to find a balance between the needs of good internal governance and the requirements of an ever more interdependent world. Commerce, communications and environmental matters transcend administrative borders; but inside those borders is where individuals carry out the first order of their economic, political and social lives. ${ }^{126}$

Therefore, if globalization is the fact or even unescapable fate, there is indeed no better choice other than participating in the evolving process of the globalizing trading framework to exercise a state's true autonomy and sovereign independence. "In committing to the WTO and its procedures and disciplines," according to the WTO 2004 Sutherland Report, "governments are returning to themselves a degree of 'sovereignty' lost through the process of globalization."127 National governments' loss of their capacity to regulate at the domestic level will be, or in fact can only be, reclaimed through some control of their economic destinies at the multilateral level. ${ }^{128}$ The WTO evolution is then an unavoidable constitutional process of international social contract on trade swallowing states, international institutions, and individuals in the global market, a process which can be made better and fairer but cannot be avoided.

\subsection{Conclusion}

Building on a brief examination of the historical evolution of the global trading regime from provisional GATT to the WTO, this chapter reveals the constitutional continuity of the development of the trading regime. During the process of development, while the regime's coverage has been extended from trade in goods to services, intellectual property rights, and trade facilitation through dispute resolution, the significance of the non-discrimination principle also grew

126 United Nations, An Agenda for Peace: Preventive Diplomacy, Peacemaking and Peacekeeping, UN Report of the Secretary-General (A/47/277-S/24,111, 31 January 1992), para. 17.

127 WTO, The Future of the WTO: Addressing Institutional Challenges in the New Millennium, Report by the Consultative Board to the Director-General Supachai Panitchpakdi (The Sutherland Report, Geneva: WTO, 2004), 34.

128 Ibid. 
from covering products to individuals in various capacities. The WTO as an international organization with a three-in-one triune personality of administrative, legislative, and judicial functions, within the framework where states hold primacy, operates ultimately for individuals' benefit. While the WTO as an intergovernmental organization in public international law leaves no space for individuals, the WTO nevertheless penetrates domestic affairs by touching on private rights either through the trade in goods mechanism (GATT) or though the intellectual property rights (TRIPS) mechanism. International trade thus appears to be an interconnecting mechanism relating states, individuals, and the WTO through the movement of goods, services, and intellectual property rights. The critical examination of the state-WTO-individual tripartite dynamics in the process of global trade's constitutional evolution offers an in-depth understanding of the nature of the WTO as an international social contract on trade.

Building on this critical conceptualization of the tripartite dynamics in international law, Chapter 2 on WTO decision-making by consensus reveals that consensus decision-making, the soul of the WTO, faces both practical and theoretical challenges. A major practical issue is that consensus involves deference to powers and problems of disenfranchisement; yet reverse consensus challenges the institutional check-and-balance against the Appellate Body's de facto judicial finality. Single undertaking, as a natural extension of consensus, creates consent fragmentation. A major theoretical issue is that the legitimacy of the principle of consensus rests on a contractarian foundation. In the same way that "general will" underlies the social compact, consensus and single undertaking underlie WTO decision-making and build their legitimacy on members' consent. Unfortunately, through contractarian justification's reference to a static “original compact" as the first mover, consensus decision-making fails to take into account the evolutionary nature of consent and runs into a legitimacy issue. This book further continues the critique of the contractarian myth of WTO jurisprudence in the area of treaty interpretation in Chapter 3 on GATT's “common intention" approach of treaty interpretation. Building on a critical examination of a high profile WTO case, the analysis of the general exception jurisprudence in China - Raw Materials, Chapter 3 offers a critique of the "common intention" approach of treaty interpretation that asserts members' common intentions via 1969 VCLT as the customary interpretative rules. As the chapter reveals, misled by the confusion developed previously on China's trading rights commitments, the Panel and Appellate Body failed to recognize the unforeseeable nature of general exceptions. A clear judicial activist tendency carried in the WTO Panel's misinterpretation of the accession protocol reveals an "origin-seeking retrospective" mechanism that locates "common intentions" statically at the founding moment of the treaty framework. This further develops a failure to apply the contingency measures that balance the rigidity of the regime and a failure to acknowledge differences and flexibility, which further undermines WTO legitimacy. Its contractarian obsession with "common intentions" as a quest for legitimate consent fails on its own terms. 
Building on the previous critical examination of WTO's jurisprudential distortion, Chapters 4 and 5 bring us back to practical cases and examine WTO's private right distortion in international movement of goods and intellectual property rights (IPRs) as private rights, as well as the implications of the private right distortion in international trade. Chapter 4 on the NME normal value determination in the antidumping regime reveals how goods and traders in "free trade" have been trapped inside an ideological divide between market vs. non-market economies. This chapter critically examines the normal value determination of NME and its implications for the purpose of contributing to Doha antidumping reform deliberation. Accompanied by significant growth of government paternalistic discretion in domestic dumping regimes and deeply rooted in an ideological divide, NME methodology's obsession with national divide turns free trade from traders' commutative exchange into nations' distributive predation. The critique suggests that when products and producers are given certain status via nationality instead of treated individually, international antidumping development becomes a process "from status to contract" and back. Beyond NME methodology's ideological distortion of trade in goods, Chapter 5 on public health and TRIPS critically examines the dynamics between public health, IPRs, and international trade in the context of the TRIPS Amendment and its theoretical implications in international law. The chapter suggests that international efforts in the TRIPS 2003 Waiver and 2005 Amendment addressing public health concerns have not been very successful due to the birth defect of TRIPS, i.e. hoping a private-rights-in-nature regime could accommodate public interests in health concerns. TRIPS' birth defect further reveals itself in post-TRIPS development and contributed to the failure of the TRIPS Waiver and Amendment due to the resulting practice fragmentation and procedural hurdles in domestic compulsory licensing administration. Moreover, the TRIPS Amendment raised a fundamental theoretical issue, i.e. how WTO as an international organization in public international law can regulate compulsory licensing of IPRs as private and negative rights - in particular the proprietary right to remuneration - while recognizing that TRIPS grants no positive rights.

Moving away from previous points of focus to distortion of goods and private right IPRs in trade, Chapter 6 on trade and policy dynamic critically examines governments' trade policy obligation as to anticompetitive practices in TRIPS. As an integral part of the WTO trading regime and in line with the international trend of antitrust control, TRIPS harmonized IP protection with competition in mind. However, diverse national FRAND enforcement practices that take either a contractual or antitrust approach challenge TRIPS integrity. While SEP's personal property recognition lends constitutional support to the contractual approach to FRAND enforcement, private property's in-built limitation warrants a balance with antitrust approach for the consideration of the needs from others. A critical examination of TRIPS' conclusion and the analytical structure of TRIPS provisions reveals that TRIPS obligation against anticompetitive practices is imperative. The imbalance of harmonized TRIPS with un-harmonized 
FRAND practices reflects TRIPS' birth defect and challenges TRIPS integrity with negative consequences to be borne by individuals.

Building on theoretical and practical critiques above, Chapter 7 concludes with a brief outlook of the future prospects of the WTO framework as an international social contract on trade. Operating within the framework where states hold primacy, the WTO nevertheless has a soul of its own for the benefit of the individuals. The book concludes with a call for reconstruction of a WTO jurisprudence that can reflect the dynamics between the force, means, and ends of the global trading regime's constitutional evolution. Hopefully this will lead us through the ongoing trade fragmentation more smoothly.

\section{Bibliography}

\section{General}

Alston, Philip. "Resisting the Merger and Acqusition of Human Rights by Trade Law: A Reply to Petersmann," 13.4 European Journal of International Law (2002), 815-844.

Cass, Deborah Z. "China and the 'Constitutionalization' of International Trade Law," in Deborah Z. Cass et al. (eds.), China and the World Trading System (Cambridge: Cambridge University Press, 2003), 40-51.

Crawford, James. Brownlie's Principles of Public International Law (Oxford: Oxford University Press, 2012, 8th ed.).

Dunoff, Jeffrey L. “Constitutional Conceits: The WTO's 'Constitution' and Discipline of International Law," 17.3 European Journal of International Law (2006), 647-675.

Henkin, Louis. International Law: Politics and Values (The Hague: Martinus Nijhoff Publishers, 1995).

Hudec, Robert E. Essays on the Nature of International Trade Law (London: Cameron May, 1999).

Jackson, John H. The World Trading System: Law and Policy of International Economic Relations (Massachusetts: MIT Press, 1997, 2nd ed.).

Jackson, John H. "Fragmentation or Unification among International Institutions: The World Trade Organization," 31 N.Y.U. Journal of International Law and Politics (1999), 823-831.

Jackson, John H. "International Economic Law in Times that are Interesting," 3 Journal of International Economic Law (2000), 3-14.

Jackson, John H. Sovereignty, The WTO and Changing Fundamentals of International Law (Cambridge: Cambridge University Press, 2006).

Jennings, Robert and Arthur Watts. Oppenheim's International Law (London: Longman Group UK Ltd., 1992, 9th ed., vol. I).

Jessup, Philip C. A Modern Law of Nations: An Introduction (New York: The Macmillan Company, 1948).

McRae, Donald M. "The WTO in International Law: Tradition Continued or New Frontier?" 3 Journal of International Economic Law (2000), 27-41.

Pauwelyn, Joost. "The Role of Public International Law in the WTO: How Far Can We Go?" 95 American Journal of International Law (2001), 535-578. 
Petersmann, Ernst-Ulrich. "From 'Negative' to 'Positive' Integration in the WTO: Time for 'Mainstreaming Human Rights' into WTO Law?" 37.6 Common Market Law Review (2000), 1363-1382.

Petersmann, Ernst-Ulrich. “Time for a United Nations 'Global Compact' for Integrating Human Rights into the Law of Worldwide Organizations: Lessons from European Integration," 13.3 European Journal of International Law (2002a), 621-650.

Petersmann, Ernst-Ulrich. "Taking Human Dignity, Poverty and Empowerment of Individuals More Seriously: Rejoinder to Alston," 13.4 European Journal of International Law (2002b), 845-851.

Rousseau, Jean-Jacques. The Social Contract (London: Penguin Books, 1968; translated by Maurice Cranston).

Schermers, Henry G. and Niels. M. Blokker. International Institutional Law (The Hague: Martinus Nijhoff Publishers, 2011, 5th ed.).

UN Documents. "Protocol of Provisional Application of the General Agreement on Tariffs and Trade," signed at Geneva on 30 October 1947, UN Treaty Series 55, 308 (1950).

UN Economic and Social Council (UN ECOSOC). Calling of an International Conference on Trade and Employment, UN Doc. E/13 (18 February 1946).

United Nation. An Agenda for Peace: Preventive Diplomacy, Peacemaking and Peace-keeping, UN Report of the Secretary-General (A/47/277-S/24111, 31 January 1992).

WTO. Trading into the Future (Geneva: WTO Publications, 2001, 2nd ed.).

WTO. The Future of the WTO: Addressing Institutional Challenges in the New Millennium, Report by the Consultative Board to the Director-General Supachai Panitchpakdi (The Sutherland Report; Geneva: WTO Publications, 2004).

WTO. World Trade Report 2017: Six Decades of Multilateral Trade Cooperation: What Have We Learnt? (Geneva: WTO Publications, 2007).

WTO. 20 Years of the WTO: A Retrospective (Geneva: WTO Publications, 2015).

\section{Cases}

EC-Hormones (US), WT/DS26/AB/R (16 January 1998).

EC-Cotton Yarn, adopted GATT Panel Report (ADP/137, 30 October 1995).

EEC - Parts and Components, adopted GATT Panel Report (L/6657 - 37S/132, 16 May 1990).

EU - Poultry Meat (China), WT/DS492/R (28 March 2017).

ICJ, Admission of a State to the United Nations (Charter, Art. 4), Individual Opinion by M. Alvarez, ICJ Reports 1948.

ICJ, Interpretation of the Agreement of 25 March 1951 between the WHO and Egypt, Advisory Opinion, Separate Opinion of Judge Gros, ICJ Reports 1980.

India-Patents(US), WT/DS50/AB/R (19 December 1997).

Japan - Alcoholic Beverages II, WT/DS8/AB/R (4 October 1996).

Korea - Government Procurement, WT/DS163/R (1 May 2000).

US - 1916 Act (Japan), WT/DS162/AB/R (28 August 2000).

US - 1916 Act (EC), WT/DS136/AB/R (28 August 2000).

US - Gasoline, WT/DS2/AB/R (29 April 1996).

US - Tuna II, adopted GATT Panel Report (DS/29/R, 16 June 1994).

US - Section 301 Trade Act, WT/DS152/R (22 December 1999). 


\section{Bibliography}

\section{General}

Alston, Philip. "Resisting the Merger and Acqusition of Human Rights by Trade Law: A Reply to Petersmann," 13.4 European Journal of International Law (2002), 815-844.

Cass, Deborah Z. "China and the 'Constitutionalization' of International Trade Law," in Deborah Z. Cass et al. (eds.), China and the World Trading System (Cambridge: Cambridge University Press, 2003), 40-51.

Crawford, James. Brownlie's Principles of Public International Law (Oxford: Oxford University Press, 2012, 8th ed.).

Dunoff, Jeffrey L. "Constitutional Conceits: The WTO's 'Constitution' and Discipline of International Law," 17.3 European Journal of International Law (2006), 647-675.

Henkin, Louis. International Law: Politics and Values (The Hague: Martinus Nijhoff Publishers, 1995).

Hudec, Robert E. Essays on the Nature of International Trade Law (London: Cameron May, 1999).

Jackson, John H. The World Trading System: Law and Policy of International Economic Relations (Massachusetts: MIT Press, 1997, 2nd ed.).

Jackson, John H. "Fragmentation or Unification among International Institutions: The World Trade Organization," 31 N.Y.U. Journal of International Law and Politics (1999), 823-831.

Jackson, John H. "International Economic Law in Times that are Interesting," 3 Journal of International Economic Law (2000), 3-14.

Jackson, John H. Sovereignty, The WTO and Changing Fundamentals of International Law (Cambridge: Cambridge University Press, 2006).

Jennings, Robert and Arthur Watts. Oppenheim's International Law (London: Longman Group UK Ltd., 1992, 9 th ed., vol. I).

Jessup, Philip C. A Modern Law of Nations: An Introduction (New York: The Macmillan Company, 1948).

McRae, Donald M. "The WTO in International Law: Tradition Continued or New Frontier?" 3 Journal of International Economic Law (2000), 27-41.

Pauwelyn, Joost. "The Role of Public International Law in the WTO: How Far Can We Go?” 95 American Journal of International Law (2001), 535-578. 
Petersmann, Ernst-Ulrich. "From 'Negative' to 'Positive' Integration in the WTO: Time for 'Mainstreaming Human Rights' into WTO Law?” 37.6 Common Market Law Review (2000), 1363-1382.

Petersmann, Ernst-Ulrich. “Time for a United Nations 'Global Compact' for Integrating Human Rights into the Law of Worldwide Organizations: Lessons from European Integration," 13.3 European Journal of International Law (2002a), 621-650.

Petersmann, Ernst-Ulrich. "Taking Human Dignity, Poverty and Empowerment of Individuals More Seriously: Rejoinder to Alston," 13.4 European Journal of International Law (2002b), 845-851.

Rousseau, Jean-Jacques. The Social Contract (London: Penguin Books, 1968; translated by Maurice Cranston).

Schermers, Henry G. and Niels. M. Blokker. International Institutional Law (The Hague: Martinus Nijhoff Publishers, 2011, 5th ed.).

UN Documents. "Protocol of Provisional Application of the General Agreement on Tariffs and Trade," signed at Geneva on 30 October 1947, UN Treaty Series 55, 308 (1950).

UN Economic and Social Council (UN ECOSOC). Calling of an International Conference on Trade and Employment, UN Doc. E/13 (18 February 1946).

United Nation. An Agenda for Peace: Preventive Diplomacy, Peacemaking and Peace-keeping, UN Report of the Secretary-General (A/47/277-S/24111, 31 January 1992).

WTO. Trading into the Future (Geneva: WTO Publications, 2001, 2nd ed.).

WTO. The Future of the WTO: Addressing Institutional Challenges in the New Millennium, Report by the Consultative Board to the Director-General Supachai Panitchpakdi (The Sutherland Report; Geneva: WTO Publications, 2004).

WTO. World Trade Report 2017: Six Decades of Multilateral Trade Cooperation: What Have We Learnt? (Geneva: WTO Publications, 2007).

WTO. 20 Years of the WTO: A Retrospective (Geneva: WTO Publications, 2015).

\section{Cases}

EC - Hormones (US), WT/DS26/AB/R (16 January 1998).

EC - Cotton Yarn, adopted GATT Panel Report (ADP/137, 30 October 1995).

EEC - Parts and Components, adopted GATT Panel Report (L/6657 - 37S/132, 16

May 1990).

EU-Poultry Meat (China), WT/DS492/R (28 March 2017).

ICJ, Admission of a State to the United Nations (Charter, Art. 4), Individual Opinion by M. Alvarez, ICJ Reports 1948.

ICJ, Interpretation of the Agreement of 25 March 1951 between the WHO and Egypt, Advisory Opinion, Separate Opinion of Judge Gros, ICJ Reports 1980.

India - Patents (US), WT/DS50/AB/R (19 December 1997).

Japan - Alcoholic Beverages II, WT/DS8/AB/R (4 October 1996).

Korea-Government Procurement, WT/DS163/R (1 May 2000).

US - 1916 Act (Japan), WT/DS162/AB/R (28 August 2000).

US - 1916 Act (EC), WT/DS136/AB/R (28 August 2000).

US - Gasoline, WT/DS2/AB/R (29 April 1996).

US - Tuna II, adopted GATT Panel Report (DS/29/R, 16 June 1994).

US - Section 301 Trade Act, WT/DS152/R (22 December 1999). 


\section{General}

Arup, Christopher. The New World Trade Organization Agreements: Globalizing Law through Services and Intellectual Property (Cambridge: Cambridge University Press, 2000).

Bacchus, James. "Groping toward Grotius: The WTO and the International Rule of Law," 44.2 Harvard International Law Journal (2003), 533-550.

Baldwin, Richard. "WTO 2.0: Global Governance of Supply-Chain Trade," Policy Insight, No. 64 (Centre for Economic Policy Research, December 2012).

Bellmann, Christophe, Jonathan Hepburn, and Marie Wilke. "The Challenges Facing the Multilateral Trading System in Addressing Global Public Policy Objectives," in Gilles Carbonnier (ed.), International Development Policy: Aid, Emerging Economies and Global Policies (London: Palgrave Macmillan, 2012), 117-140.

Bhagwati, Jagdish. "Fifty Years: Looking Back, Looking Forward," in the WTO Secretariat (ed.), From GATT to the WTO: The Multilateral Trading System in the New Millennium (The Netherlands: Kluwer Law International, 2000), 57-65.

Bourgeois, Jacques. "The Umpire Needs Better Rules of the Game," in Giorgio Sacerdoti, Alan Yanovich and Jan Bohanes (eds.), The WTO at Ten: The Contribution of the Dispute Settlement System (Cambridge: Cambridge University Press, 2006), 235-245.

Brand, Ronald A. "Sovereignty: The State, the Individual, and the International Legal System in the Twenty First Century," 25 Hastings International and Comparative Law Review (2002), 279-295.

Brinza, Daniel. "DSU Reform: If It Is Not Broken - Improve It?" in Giorgio Sacerdoti, Alan Yanovich and Jan Bohanes (eds.), The WTO at Ten: The Contribution of the Dispute Settlement System (Cambridge: Cambridge University Press, 2006), 246-258.

Brownlie, Ian. The Rule of Law in International Affairs: International Law at the Fiftieth Anniversary of the United Nations (The Hague Leiden: Martinus Nijhoff Publishers, 1998).

Carty, Anthony. "Introduction: Post-Modern Law," in Anthony Carty (ed.), PostModern Law: Enlightenment, Revolution and the Death of Man (Edinburgh: Edinburgh University Press, 1990), 1-38.

Conti, Joseph A. Between Law and Diplomacy: The Social Contexts of Disputing at the World Trade Organization (Stanford, CA: Stanford University Press, 2011).

Cottier, Thomas. "Resolving Underlying Balance-of-power Issues," in Giorgio Sacerdoti, Alan Yanovich and Jan Bohanes (eds.), The WTO at Ten: The Contribution of the Dispute Settlement System (Cambridge: Cambridge University Press, 2006), 259-265.

Cottier, Thomas. "The Legitimacy of WTO Law," in Linda Yueh (ed.), The Law and Economics of Globalisation: New Challenges for a World in Flux (Cheltenham: Edward Elgar Publishing, 2009), 11-48.

Cottier, Thomas. "A Two-Tier Approach to WTO Decision-Making," in Debra P. Steger (ed.), Redesigning the World Trade Organization for the Twenty-first Century (Ottawa: Wilfrid Laurier University Press, 2010), 43-66.

Deere Birkbeck, Carolyn and Catherine Monagle. Strengthening Multilateralism: A Mapping of Proposals on WTO Reform and Global Trade Governance (Geneva/ Oxford: ICTSD and the Global Economic Governance Programme, 2009). 
Delbrück, J. "Exercising Public Authority beyond the State: Transnational Democracy and/or Alternative Legitimation Strategies?" 32 Indiana Journal of Global Legal Studies (2003), 29-43.

Dworkin, Ronald. Law's Empire (Cambridge, MA: Belknap Press, 1986).

Ehlermann, Claus-Dieter and Lothar Ehring. "The Authoritative Interpretation under Article IX:2 of the Agreement Establishing the World Trade Organization: Current Law, Practice and Possible Improvements," 8.4 Journal of International Economic Law (2005), 803-824.

Elsig, Manfred. "WTO Decision-Making: Can We Get a Little Help from the Secretariat and the Critical Mass?" in Debra P. Steger (ed.), Redesigning the World Trade Organization for the Twenty-first Century (Ottawa: Wilfrid Laurier University Press, 2010), 67-90.

GATT Secretariat. Non-Violation Complaints under GATT Article XXIII:2 (MTN. GNG/NGl3/W/31, 1 July 1989).

Hayek, F. A. The Constitution of Liberty (Chicago: University of Chicago Press, 1960). Hayek, F. A. The Fatal Conceit: The Errors of Socialism (Abingdon: Routledge, 1988).

Heisenberg, Dorothee. "Informal Decision-Making in the Council: The Secret of the EU's Success?" in Sophie Meunier and Kathleen R. McNamara (eds.), Making History: European Integration and Institutional Change at Fifty (New York: Oxford University Press, 2007), 67-88.

Henkin, Louis. Constitutionalism, Democracy, and Foreign Affairs (New York: Columbia University Press, 1990).

Henkin, Louis. "The Mythology of Sovereignty," in R. St. J. Macdonald (ed.), Essays in Honour of Wang Tieya (Dordrecht: Martinus Nijhoff, 1993), 351-358.

Henkin, Louis. International Law: Politics and Values (The Hague: Kluwer Academic Publishers, 1995).

Hindley, Brian. "What Subjects are Suitable for WTO Agreement?" in Daniel L.M. Kennedy and James D. Southwick (eds.), The Political Economy of International Trade Law: Essays in Honor of Robert E. Hudec (New York: Cambridge Unviersity Press, 2002), 157-170.

Howse, Robert. "The Most Dangerous Branch? WTO Appellate Body Jurisprudence on the Nature and Limits of the Judicial Power," in T. Cottier, P.C. Mavroidis and P. Blatter (eds.), The Role of the Judge in International Trade Regulation: Experience and Lessons for the WTO (Ann Arbor: University of Michigan Press, 2003), 11-42.

Hudec, Robert E. Essays on the Nature of International Trade Law (London: Cameron May, 1999).

Hufbauer, Gary Clyde and Jeffrey J. Schott. "Will the World Trade Organization Enjoy a Bright Future?" Policy Brief, PB12-11 (Peterson Institute for International Economics, May 2012).

Hughes, Valerie. "The WTO Dispute Settlement System - From Initiating Proceedings to Ensuring Implementation: What Needs Improvement?" in Giorgio Sacerdoti, Alan Yanovich, and Jan Bohanes (eds.), The WTO at Ten: The Contribution of the Dispute Settlement System (Cambridge: Cambridge University Press, 2006), 193-234.

International Law Commission. Yearbook of the International Law Commission 1966 (New York: UN, 1966, vol. 2).

Ismail, Faizel and Brendan Vickers, "Towards Fair and Inclusive Decision-making in WTO Negotiations," in Carolyn Deere Birkbeck (ed.), Making Global Trade 
Governance Work for Development: Perspectives and Priorities from Developing Countries (Cambridge: Cambridge University Press, 2011).

Jackson, John H. "The WTO Dispute Settlement Procedures: A Preliminary Appraisal," in Jeffrey J. Schott (ed.), The World Trading System: Challenges Ahead (Washington, DC: Institute for International Economics, 1996), 153-165.

Jackson, John H. The World Trading System: Law and Policy of International Economic Relations (Cambridge, MA: MIT Press, 1997, 2nd ed.).

Jackson, John H. The Jurisprudence of GATT \& the WTO: Insights on Treaty Law and Economic Relations (Cambridge: Cambridge University Press, 2000).

Jackson, John H. Sovereignty, the WTO and Changing Fundamentals of International Law (Cambridge: Cambridge University Press, 2006).

Jennings, Robert and Arthur Watts. Oppenheim's International Law (London: Longman Group UK Ltd., 1992, 9th ed., vol. I).

Lawrence, Robert Z. "Rulemaking Amidst Growing Diversity: A Club-of-Clubs Approach to WTO Reform and New Issue Selection," 9.4 Journal of International Economic Law (2006), 823-835.

Lee, Roy S. "Multilateral Treaty-making and Negotiation Techniques: An Appraisal," in B. Cheng and E.D. Brown eds., Contemporary Problems of International Law: Essays in Honour of Georg Schwarzenberger on His Eightieth Birthday (London: Stevens \& Sons Ltd., 1988), 157-176.

Levy, Philip I. "Do We Need an Undertaker for the Single Undertaking? Considering the Angles of Variable Geometry," in Simon J. Evenett and Bernard M. Hoekman (eds.), Economic Development and Multilateral Trade Cooperation (New York: Palgrave Macmilan, 2006), 417-437.

Low, Patrick. "WTO Decision-Making for the Future," WTO Staff Working Paper ERSD-2011-05 (2 May 2011).

Maine, Henry. Ancient Law (London: J.M. Dent \& Sons Ltd., 1917).

Mendoza, Miguel Rodriguez and Marie Wilke. "Revisiting the Single Undertaking: Towards a More Balanced Approach to WTO Negotiations," in Carolyn Deere Birkbeck (ed.), Making Global Trade Governance Work for Development: Perspectives and Priorities from Developing Countries (Cambridge: Cambridge University Press, 2011), 486-506.

Merquior, J. G. Roussean and Weber: Two Studies in the Theory of Legitimacy (London: Routledge \& Kegan Paul, 1980).

Mitchell, Andrew. "Due Process in WTO disputes," in Rufus Yerxa and Bruce Wilson (eds). Key Issues in WTO Dispute Settlement: The First Ten Year (Cambridge: Cambridge University Press, 2005), 144-160.

Narlikar, Amrita. World Trade Organization: A Very Short Introduction (Oxford: Oxford University Press, 2005).

Oesch, Matthias. Standards of Review in WTO Dispute Resolution (Oxford: Oxford University Press, 2003).

Panitchpakdi, Supachai. "The WTO at Ten: Building on Ten Years of Achievements," in Giorgio Sacerdoti, Alan Yanovich and Jan Bohanes (eds.), The WTO at Ten: The Contribution of the Dispute Settlement System (Cambridge: Cambridge University Press, 2006), 7-12.

Pauwelyn, Joost. "The Nature of WTO Obligations," Jean Monnet Working Paper No. 1/02 (2002).

Pauwelyn, Joost. "The Role of Public International Law in the WTO: How Far Can We Go?" 95 The American Journal of International Law (2001), 535-578. 
Petersmann, Ernst-Ulrich. The GATT/WTO Dispute Settlement System: International Law, International Organizations and Dispute Settlement (London: Kluwer Law International, 1997).

Rawls, John. A Theory of Justice (Cambridge, MA: Belknap Press, 1999, rev. ed.).

Rousseau, Jean-Jacques. The Social Contract (London: Penguin Books, 1968, translated by Maurice Cranston).

Ruggiero, Renato. "The Future Path of the Multilateral Trading System," speech delivered at Seoul, Korea on 17 April 1997.

Schott, Jeffrey J. "Challenges Facing the World Trade Organization," in Jeffrey J. Schott (ed.), The World Trading System: Challenges Ahead (Washington, DC: Institute for International Economics, 1996), 3-24.

Siebert, Horst. "What Does Globalization Mean for the World Trading System?" in the WTO Secretariat (ed.), From GATT to the WTO: The Multilateral Trading System in the New Millennium (London: Kluwer Law International, 2000), 137-166.

Steinberg, Richard H. "In the Shadow of Law or Power? Consensus-Based Bargaining and Outcomes in the GATT/WTO," 56.2 International Organization (Spring, 2002), 339-374.

UNIDO. Public Goods for Economic Development (Vienna: UNIDO, 2008).

University of Warwick, The Multilateral Trade Regime: Which Way Forwards? The report of the first Warwick Commission (2007).

Van Damme, Isabelle. Treaty Interpretation by the WTO Appellate Body (Oxford: Oxford University Press, 2009).

Van den Bossche, Peter. "The Making of the 'World Trade Court': The Origins and Development of the Appellate Body of the World Trade Organization," in Rufus Yerxa and Bruce Wilson (eds.), Key Issues in WTO Dispute Settlement: The First Ten Years (Cambridge: Cambridge University Press, 2005), 63-79.

VanGrasstek, Craig and Pierre Sauvé. "The Consistency of WTO Rules: Can the Single Undertaking Be Squared with Variable Geometry?" 9.4 Journal of International Economic Law (2006), 837-864.

Wolfe, Robert. "Arguing and Bargaining in the WTO: Does the Single Undertaking Make a Difference?" Paper prepared for presentation to the Canadian Political science Association (Vancouver, Canada, June 4-6, 2008).

WTO, World Trade Report 2009: Trade Policy Commitments and Contingency Measures (Geneva: WTO Publications, 2009).

Yerxa, Rufus. "The Power of the WTO Dispute Settlement System," in Rufus Yerxa and Bruce Wilson (eds.), Key Issues in WTO Dispute Settlement: The First Ten Years (Cambridge: Cambridge University Press, 2005), 3-6.

Ziegler, Andreas R. and Yves Bonzon, "How to Reform WTO Decision-making? an Analysis of the Current Functioning of the Organization from the Perspective of Efficiency and Legitimacy," NCCR Trade Regulation Working Paper No. 2007/23 (May 2007).

\section{Cases}

Brazil-Desiccated Coconut, WT/DS22/AB/R (21 February 1997).

EC-Aircraft, WT/DS316/AB/R (18 May 2011). 
EC - Bananas III (Article 21.5 - Ecuador), WT/DS27/AB/RW2/ECU (26 November 2008).

EC-Chicken Cuts, WT/DS269/286/AB/R (12 September 2005).

EC-Computer Equipment, WT/DS62/AB/R (5 June 1998).

EC-Hormones (US), WT/DS26/AB/R (16 January 1998).

ICJ, Rights of United States of America in Morocco, ICJ Reports 1952.

ICJ, Legal Consequences for States of the Continued Presence of South Africa in Namibia (South West Africa) notwithstanding Security Council Resolution 276 (1970), Advisory Opinion, ICJ Reports 1971.

Japan - Film, WT/DS44/R (21 March 1998).

Japan - Alcoholic Beverages II, WT/DS8/AB/R (4 October 1996).

Thailand-Cigarettes (Philippines), WT/DS371/AB/R (17 June 2011).

US - Gambling, WT/DS285/AB/R (7 April 2005).

US - Shrimp, WT/DS58/AB/R (12 October 1998).

US - Wool Shirts and Blouses, WT/DS33/AB/R (25 April 1997).

\section{General}

Ala'i, Padideh. "Free Trade or Sustainable Development? An Analysis of the WTO Appellate Body's Shift to a More Balanced Approach to Trade Liberalization," 14.4 American University International Law Review (1999), 1129-1171.

Arup, Christopher. The New World Trade Organization Agreements: Globalizing Law through Services and Intellectual Property (Cambridge: Cambridge University Press, 2000).

Brand, Ronald A. "Sovereignty: The State, the Individual, and the International Legal System in the Twenty First Century," 25 Hastings International and Comparative Law Review (2002), 279-295.

Brownlie, Ian. Principles of Public International Law (Oxford: Oxford University Press, 2008, 7th ed.).

Davies, Margaret. Delimiting the Law: Postmodernism and the Politics of Law (London and Chicago: Pluto Press, 1996).

Delbrück, J. "Exercising Public Authority beyond the State: Transnational Democracy And/or Alternative Legitimation Strategies?" 32 Indiana Journal of Global Legal Studies (2003), 29-43.

Ehlermann, Claus-Dieter and Lothar Ehring. "The Authoritative Interpretation under Article IX:2 of the Agreement Establishing the World Trade Organization: Current Law, Practice and Possible Improvements," 8.4 Journal of International Economic Law (2005), 803-824.

Fitzmaurice, G. G. "The Law and Procedure of the International Court of Justice: Treaty Interpretation and Certain Other Treaty Points," 28 British Year Book of International Law (1951), 1-28.

Garner, Bryan A. Black's Law Dictionary (St. Paul, MN: Thomson Reuters, 2009, 9th ed.).

Henkin, Louis. Constitutionalism, Democracy, and Foreign Affairs (New York: Columbia University Press, 1990).

Henkin, Louis. "The Mythology of Sovereignty," in R. St. J. Macdonald (ed.), Essays in Honour of Wang Tieya (Dordrecht: Martinus Nijhoff, 1993), 351-358.

Henkin, Louis. International Law: Politics and Values (The Hague: Kluwer Academic Publishers, 1995). 
Howse, Robert. "The Most Dangerous Branch? WTO Appellate Body Jurisprudence on the Nature and Limits of the Judicial Power," in T. Cottier, P.C. Mavroidis and P. Blatter (eds.), The Role of the Judge in International Trade Regulation: Experience and Lessons for the WTO (Ann Arbor, MI: University of Michigan Press, 2003), $11-42$.

Hudec, Robert E. Essays on the Nature of International Trade Law (London: Cameron May, 1999).

ILC, Yearbook of the International Law Commission 1949 (YILC, 1949).

ILC, Yearbook of the International Law Commission 1965 (YILC, 1965), vol. 2.

ILC, Yearbook of the International Law Commission 1966 (YILC, 1966), vol. 2.

Jackson, John H. "The WTO Dispute Settlement Procedures: A Preliminary Appraisal," in Jeffrey J. Schott (ed.), The World Trading System: Challenges Ahead (Washington, DC: Peterson Institute, 1996), 153-165.

Jackson, John H. The World Trading System: Law and Policy of International Economic Relations (Cambridge, MA: MIT Press, 1997, 2nd ed.).

Jackson, John H. Sovereignty, the WTO, and Changing Fundamentals of International Trade Law (Cambridge: Cambridge University Press, 2006).

Jennings, Robert and Arthur Watts. Oppenheim's International Law (London: Longman Group UK Ltd., 1992, 9th ed., vol. I).

Lee, Roy S. "Multilateral Treaty-making and Negotiation Techniques: An Appraisal," in B. Cheng and E.D. Brown (eds.), Contemporary Problems of International Law: Essays in Honour of Georg Schwarzenberger on His Eightieth Birthday (London: Stevens \& Sons Ltd., 1988), 157-176.

Maine, Henry. Ancient Law (London: J.M. Dent \& Sons Ltd., 1917).

Merquior, J. G. Roussean and Weber: Two Studies in the Theory of Legitimacy (London: Routledge \& Kegan Paul, 1980).

Oesch, Matthias. Standards of Review in WTO Dispute Resolution (Oxford: Oxford University Press, 2003).

Pauwelyn, Joost "The Role of Public International Law in the WTO: How Far Can We Go?" 95 The American Journal of International Law (2001), 535-578.

Pauwelyn, Joost. "The Nature of WTO Obligations," Jean Monnet Working Paper No. 1/02 (2002).

Qin, Julia Ya. “The Predicament of China's 'WTO-Plus' Obligation to Eliminate Export Duties: A Commentary on the China-Raw Materials Case," Editorial Comments, 11 Chinese Journal of International Law (2012), 237-246.

Roessler, F. "Are the Judicial Organs of the World Trade Organization Overburdened?" in R.B. Porter, P. Sauve and A. Subramanian (eds.), Efficiency, Equity, \& Legitimacy: The Multilateral Trading System in the Millennium (Washington, DC: Brookings Institution Press, 2001), 308-328.

Rousseau, Jean-Jacques. The Social Contract (London: Penguin Books, 1968; translated by Maurice Cranston).

Secretariat, GATT, "Negotiating Group on GATT Articles: Article XXI," MTN. GNG/NG7/W/16 (18 August 1987).

Secretariat, GATT, “Non-Violation Complaints under GATT Article XXIII:2," MTN. GNG/NG13/W/31 (1 July 1989).

Van Calster, Geert. "China, Minerals Export, Raw and Rare Earth Materials: A Perfect Storm for World Trade Organization Dispute Settlement," 22.1 Review of European Community \& International Environmental Law (2013), 117-122. 
Van Damme, Isabelle. "The Interpretation of Schedules of Commitments," 41.1 Journal of World Trade (2007), 1-52.

Van Damme, Isabelle. Treaty Interpretation by the WTO Appellate Body (Oxford: Oxford University Press, 2009).

Van Damme, Isabelle. "Treaty Interpretation by the WTO Appellate Body," 21.3 European Journal of International Law (2010), 605-648.

Venzke, Ingo. "Making General Exceptions: The Spell of Precedents in Developing Article XX GATT into Standards for Domestic Regulatory Policy," 12.5 German Law Journal (2011), 1111-1140.

WTO, Report of the Working Party on the Accession of China, Working Party Report, WT/ACC/CHN/49 (1 October 2001).

WTO, The Future of the WTO: Addressing Institutional Challenges in the New Millennium, Report by the Consultative Board to the Director-General Supachai Panitchpakdi (The Sutherland Report; Geneva: WTO Publications, 2004).

WTO, World Trade Report 2009: Trade Policy Commitments and Contingency Measures (Geneva: WTO Publications, 2009).

\section{Cases}

Argentina - Footwear (EC), WT/DS121/AB/R (14 December 1999).

Brazil-Desiccated Coconut, WT/DS22/AB/R (21 February 1997).

Canada - Dairy, WT/DS103/AB/R (13 October 1999).

Canada - Patent Term, WT/DS170/AB/R (18 September 2000).

China - Auto Parts, WT/DS339/AB/R (15 December 2008).

China - Publications and Audiovisual Products, WT/DS363/AB/R (21 December 2009).

China - Rare Earths, WT/DS431/432/433/AB/R (29 August 2014).

China - Raw Materials, WT/DS398/AB/R (30 January 2012).

EC-Aircraft, WT/DS316/AB/R (18 May 2011).

EC-Asbestos, WT/DS135/R (18 September 2000).

EC - Bananas (21.5 II - Ecuador), WT/DS27/AB/RW2/ECU (26 November 2008).

EC - Bananas III, WT/DS27/AB/R (9 September 1997).

EC-Chicken Cuts, WT/DS269/AB/R (12 September 2005).

EC - Computer Equipment, WT/DS62/AB/R (5 June 1998).

EC-Hormones (US), WT/DS26/AB/R (16 January 1998).

EC-Poultry, WT/DS69/AB/R (13 July 1998).

EEC - Apples (US), adopted GATT Panel Report BISD 36S/135 (22 June 1989).

EEC - Dessert Apples (Chile), adopted GATT Panel Report, BISD 36S/93 (22 June 1989).

ICJ, Rights of United States of America in Morocco, ICJ Reports 1952.

ICJ, Legal Consequences for States of the Continued Presence of South Africa in

Namibia (South West Africa) notwithstanding Security Council Resolution 276 (1970), Advisory Opinion, ICJ Reports 1971.

India-Patents (EC), WT/DS79/R (24 August 1998).

India-Patents (US), WT/DS50/AB/R (19 December 1997).

Japan - Alcoholic Beverages II, WT/DS8/AB/R (4 October 1996).

Japan - Film, WT/DS44/R (31 March 1998). 
Korea - Dairy, WT/DS98/AB/R (14 December 1999).

Korea-Procurement, WT/DS163/R (1 May 2000).

Korea - Various Measures on Beef, WT/DS161/AB/R (11 December 2000).

Mexico - Telecoms, WT/DS204/R (2 April 2004).

Thailand - Cigarettes, adopted GATT panel report (DS10/R - 37S/200, 7 November 1990).

Thailand - Cigarettes (Philippines), WT/DS371/AB/R (17 June 2011).

US - Anti-Dumping and Countervailing Duties (China), WT/DS379/AB/R (11 March 2011).

US - Canadian Tuna, adopted GATT Panel Report, L/5198 - 29S/91 (22 February 1982).

US - Cotton Yarn, WT/DS192/AB/R (8 October 2001).

US - DRAMS, WT/DS99/R (29 January 1999).

US - Export Restraints, WT/DS194/R (29 June 2001).

US - Gambling, WT/DS285/R (10 November 2004); WT/DS285/AB/R (7 April 2005).

US - Gasoline, WT/DS2/AB/R (29 April 1996).

US - Line Pipe, WT/DS202/AB/R (15 February 2002).

US - Section 211 Appropriations Act, WT/DS176/AB/R (2 January 2002).

US - Section 301 Trade Act, WT/DS152/R (22 December 1999).

US - Shrimp, WT/DS58/R (15 May 1998).

US - Softwood Lumber V, WT/DS/264/AB/R (11 August 2004).

US - Stainless Steel (Mexico), WT/DS344/R (20 December 2007).

US - Tuna (EEC), unadopted Panel Report, DS29/R (16 June 1994).

US - Tuna (Mexico), unadopted Panel Report, DS21/R - 39S/155 (3 September 1991).

US - Tyres (China), WT/DS399/AB/R (5 September 2011).

US - Underwear, WT/DS24/AB/R (10 February 1997).

US - Upland Cotton, WT/DS/267/AB/R (3 March 2005).

US - Wool Shirts and Blouses, WT/DS33/AB/R (25 April 1997).

\section{General}

Aggarwal, Aradhna. The Anti-Dumping Agreement and Developing Countries: An Introduction (New Delhi: Oxford University Press, 2007).

Bacchus, James "Groping toward Grotius: The WTO and the International Rule of Law," 44.2 Harvard International Law Journal (2003), 533-550.

Brand, Ronald A. "Sovereignty: The State, the Individual, and the International Legal System in the Twenty First Century," 25 Hastings International and Comparative Law Review (2002), 279-295.

Brownlie, Ian. Principles of Public International Law (New York: Oxford University Press, 2008, 7th ed.).

Brownlie, Ian. Rule of Law in International Affairs (The Netherlands: Martinus Nijhoff Publishers, 1998).

Costa, Pietro. "The Rule of Law: A Historical Introduction," in Pietro Costa and Danilo Zolo (eds.), The Rule of Law: History, Theory and Criticism (New York: Springer, 2007), 73-149. 
Cuneo, Donald L. and Charles B. Manuel Jr. "Roadblock to Trade: The State-Controlled Economy Issue in Antidumping Law Administration," 5 Fordham International Law Journal (1981), 277-317.

Deardorff, Alan V. "Economic Perspectives on Antidumping Law," in Jackson and Edwin (eds.), Antidumping Law and Practice: A Comparative Study (Ann Arbor: University of Michigan Press, 1990), 23-39.

Fergusson, Ian F. World Trade Organization Negotiations: The Doha Development Agenda, Congressional Research Service Report (Washington DC: Congressional Research Service, December, 2011).

Finger, J. Michael. (ed.). Antidumping: How It Works and Who Gets Hurt (Ann Arbor: University of Michigan Press, 1993).

Franck, Thomas M. The Empowered Self: Law and Society in the Age of Individualism (New York: Oxford University Press, 1999).

Hayek, F. A. The Constitution of Liberty (Chicago: The University of Chicago Press, 1960).

Henkin, Louis. International Law: Politics and Values (The Hague: Kluwer Academic Publishers, 1995).

Hindley, Brian and Patrick A. Messerlin, Antidumping Industrial Policy: Legalized Protectionism in the WTO and What to Do about It (Washington, DC: The AEI Press, 1996).

Hobbes, Thomas. Leviathan (London: Penguin Books, 1968).

Hudec, R. "Comment on 'The Club Model of Multilateral Cooperation and Problems of Democratic Legitimacy'," in R. Porter et al. eds., Efficiency, Equity, and Legitimacy: The Multilateral Trading System at the Millennium (Washington, DC: Brookings Institution Press, 2001), 297-298.

Jackson, John H. and Edwin A. Vermulst (eds.). Antidumping Law and Practice: A Comparative Study (Ann Arbor, MI: University of Michigan Press, 1990).

Jennings, Robert and Arthur Watts, Oppenheim's International Law (London: Longman Group UK Ltd., 1992, 9th ed.).

Lindsey, Brink and Daniel J. Ikenson. Antidumping Exposed: The Devilish Details of Unfair Trade Law (Washington, DC: Cato Institute, 2003).

Locke, John. The Second Treatise of Government (New Jersey: Prentice Hall, 1997).

Lynam, Garrett E. "Using WTO Countervailing Duty Law to Combat Illegally Subsidized Chinese Enterprises Operating in a Nonmarket-Economy: Deciphering the Writing on the Wall," 42.3 Case Western Reserve Journal of International Law (2010), 739-773.

Maine, Henry. Ancient Law (London: J. M. Dent \& Sons Ltd., 1917).

Malanczuk, Peter. Akehurst's Modern Introduction to International Law (London: Routledge, 1997, 7th ed.).

Mason, Kenneth R. Electric Golf Cars from Poland (US International Trade Commission, June 1980).

Mastel, Grey. Antidumping Laws and the U.S. Economy (New York: M.E. Sharpe, 1998).

McGee, Robert W. A Trade Policy for Free Societies: The Case against Protectionism (Connecticut: Quorum Books, 1994).

Neufeld, Inge Nora. Anti-dumping and Countervailing Procedures - Use or Abuse? Implications for Developing Countries (Geneva: United Nations, 2001).

Petersmann, Ernst-Ulrich. Constitutional Functions and Constitutional Problems of International Economic Law: International and Domestic Foreign Trade Law and 
Foreign Trade Policy in the United States, the European Community and Switzerland (Fribourg, Switzerland: University Press, 1991).

Pierce, Kenneth J. and Matthew R. Nicely. “Transitioning to China's Market Economy Anti-dumping Treatment in 2016," American Bar Association 2009 Spring Meeting Supplementary Materials (16 February 2013).

Perez, Antonio F. "International Antitrust at the Crossroads: The End of Antitrust History or the Clash of Competition Polity Civilizations?" 33 Law and Policy in International Business (2002), 527-554.

Rao, Weijia. "China's Market Economy Status under WTO Antidumping Law after 2016," 5 Tsinghua China Law Review (2013), 151-168.

Raslan, Reem and Anwar Ahmed. Antidumping: A Developing Country Perspective (London: Kluwer Law International, 2009).

Rousseau, Jean-Jacques. The Social Contract (London: Penguin Books, 1968, translated by Maurice Cranston).

Tietje, Christian and Karsten Nowrot, "Myth or Reality? China's Market Economy Status under WTO Anti-dumping Law after 2016," Policy Papers on Transnational Economic Law (Transnational Economic Law Research Center, Martin-LutherUniversity, December 2011, vol. 34).

US Congressional Budget Office (CBO), Congress of the United States. How the GATT Affects U.S. Antidumping and Countervailing-Duty Policy (Washington, DC: CBO, 1994).

US, Notice of Final Determination of Sales at Less than Fair Value: Certain Frozen and Canned Warmwater Shrimp from the People's Republic of China, 69 FR 70997 (8 December 2004).

US, Notice of Final Determination of Sales at Less than Fair Value: Certain Tissue Paper Products from the People's Republic of China, 70 FR 7475 (14 February 2005a).

US, Notice of Final Determination of Sales at Less than Fair Value and Affirmative Critical Circumstances: Magnesium Metal from the People's Republic of China, 70 FR 9037 (24 February 2005b).

US, The People's Republic of China (PRC) Status as a Non-Market Economy (NME): Memorandum for David Spooner, Assistant Secretary for Import Administration, A570-901 (15 May 2006).

US House of Representatives Committee on Ways and Means, Overview and Compilation of US Trade Statues 2013 (January 2013).

Vermulst, Edwin. The WTO Anti-Dumping Agreement: A Commentary (New York: Oxford University Press, 2005).

Verrill, Jr. Charles Owen. "Nonmarket Economy Dumping: New Directions in Fair Value Analysis," 1989.2 Brigham Young University Law Review (1989), 449-457.

WTO, Declaration of the Fourth Ministerial Conference in Doha, Qatar, WT/MIN (01)/DEC/1 (14 November 2001).

WTO Negotiating Group on Rules, Proposal of the People's Republic of China on the Negotiation on Anti-Dumping, TN/RL/W/66 (6 March 2003).

WTO, WTO Committee on Anti-Dumping Practices, Minutes of the Regular Meeting Held on 24-25 October 2002, G/ADP/M/22 (21 March 2003).

WTO, Declaration of the Sixth Ministerial Conference in Hong Kong, WT/MIN(05) DEC (18 December 2005). 
WTO, WTO Working Party on the Accession of Viet Nam, Accession of Viet Nam: Report of the Working Party on the Accession of Viet Nam, WT/ACC/VNM/48 (27 October 2006).

WTO, Draft Consolidated Chair Texts of the AD and SCM Agreements, TN/RL/W/ 213 (30 November 2007).

WTO, New Draft Consolidated Chair Texts of the AD and SCM Agreements, TN/ RL/W/236 (19 December 2008).

WTO, WTO Committee on Subsidies and Countervailing Measures, Minutes of the Regular Meeting Held on 26-27 October 2011, G/SCM/M/79 (2 February 2012).

WTO, WTO Trade Policy Review Body, Trade Policy Review: United States (Record of the Meeting), WT/TPR/M/275 (30 April 2013).

Yerxa, Rufus and Bruce Wilson eds. Key Issues in WTO Dispute Settlement: The First Ten Years (Cambridge: Cambridge University Press, 2005).

Zolo, Danilo. "The Rule of Law: A Critical Reappraisal," in Pietro Costa and Danilo Zolo (eds.), The Rule of Law: History, Theory and Criticism (New York: Springer, 2007), 3-71.

\section{Cases}

EC-Fasteners, WT/DS397/AB/R (15 July 2011).

PCIJ Advisory Opinion Concerning the Tunis and Morocco Nationality Decrees, $1923 \mathrm{P}$. C.I.J. (ser. B) No. 4.

US - Anti-Dumping and Countervailing Duties (China), WT/DS379/AB/R (11 March 2011).

US - Gasoline, WT/DS2/AB/R (29 April 1996).

US - Malt Beverages, adopted GATT Panel Report, DS23/R - 39S/206 (19 June 1992).

US - Offset Act, WT/DS217/AB/R, WT/DS234/AB/R (16 January 2003).

US - Section 301 Trade Act, WT/DS152/R (22 December 1999).

US - Shrimp, WT/DS58/AB/R (12 October 1998).

US - Tuna (Mexico), unadopted GATT Panel Report, DS21/R - 39S/155 (3 September 1991).

\section{General}

Abbott, Frederick, M. and Jerome H. Reichman. "The Doha Round's Public Health Legacy: Strategies for the Production and Diffusion of Patented Medicines under the Amended TRIPS Provisions," 10 Journal of International Economic Law (2007), 921-987.

Abbott, Frederick M. "Technology and State Enterprise in the WTO," in Thomas Cottier and Petros C. Mavroidis (eds.), World Trade Forum: State Trading in the Twenty-First Century (1998), 121-150.

Abbott, Frederick M. "The TRIPS-Legality of Measures Taken to Address Public Health Crises: A Synopsis," 7 Widener Law Symposium Journal (2001), 71-85.

Abbott, Frederick M. "The Doha Declaration on the TRIPS Agreement and Public Health: Lighting A Dark Corner at the WTO," 5 Journal of International Economic Law (2002), 469-505. 
Abbott, Frederick M. "The WTO Medicines Decision: World Pharmaceutical Trade and the Protection of Public Health," 99 The American Journal of International Law (2005), 317-358.

Bhagwati, Jagdish N. In Defense of Globalization: With a New Afterword by the Author (Oxford: Oxford University Press, 2007).

Brand, Ronald A. "Sovereignty: The State, the Individual, and the International Legal System in the Twenty First Century," 25 Hastings International and Comparative Law Review (2002), 279-295.

Brownlie, Ian. The Rule of Law in International Affairs: International Law at the Fiftieth Anniversary of the United Nations (The Hague: Martinus Nijhoff Publishers, 1998).

Brownlie, Ian. Principles of Public International Law (Oxford: Oxford University Press, 2008, 7th ed.).

Canada. "Notification under Paragraph 2(c) of the Decision of 30 August 2003 on the Implementation of Paragraph 6 of the Doha Declaration on the TRIPS Agreement and Public Health," IP/N/10/CAN/1 (8 October 2007).

Correa, Carlos María. Integrating Public Health Concepts into Patent Legislation in Developing Countries (Geneva: South Centre, 2000).

Crawford, James. Brownlie's Principles of Public International Law (Oxford: Oxford University Press, 2012, 8th ed.).

Davison, Mark and Patrick Emerton. "Rights, Privileges, Legitimate Interests, and Justifiability: Article 20 of TRIPS and Plain Packaging of Tobacco," 29.3 American University International Law Review (2014), 505-580.

De Carvalho, Nuno Pires. The TRIPS Regime of Patent Rights (The Hague: Wolters Kluwer, 2010, 3rd ed.).

Dinwoodie, Graeme B. and Rochelle C. Dreyfuss. "Designing A Global Intellectual Property System Responsive to Change: The WTO, WIPO, and Beyond," 46 Houston Law Review (2009), 1187-1234.

Dreyfuss, Rochelle Cooper and Andreas F. Lowenfeld. "Two Achievements of the Uruguay Round: Putting TRIPS and Dispute Settlement Together," 37 Virginia Journal of International Law (1997), 275-333.

EC, "Guidelines Proposed by the European Community for the Negotiations on Trade-Related Aspects of Intellectual Property Rights: Communication from the EC to Negotiating Group on Trade-Related Aspects of Intellectual Property Rights Including Trade in Counterfeit Goods," MTN.GNG/NGl1/W/16 (20 November 1987).

Ford, Sara M. "Compulsory Licensing Provisions under the TRIPS Agreement: Balancing Pills and Patents," 15 American University International Law Review (2000), 941-974.

Garcia-Castrillón, Carmen Otero. "An Approach to the WTO Ministerial Declaration on the TRIPS Agreement and Public Health," 5 Journal of International Economic Law (2002), 212-219.

Garner, Bryan A. Black's Law Dictionary (St. Paul, MN: Thomson Reuters, 2009, 9th ed.).

Gervais, Daniel J. "Intellectual Property, Trade \& Development: The State of Play," 74 Fordham Law Review (2005), 505-535.

Guan, Wenwei. "The Poverty of Intellectual Property Philosophy," 38 Hong Kong Law Journal (2008), 359-397. 
Guan, Wenwei. Intellectual Property Theory and Practice: A Critical Examination of China's TRIPS Compliance and Beyond (Heidelberg: Springer, 2014).

Helfer Laurence, R. and Graeme W. Austin. Human Rights and Intellectual Property: Mapping the Global Interface (Cambridge: Cambridge University Press, 2011).

Henkin, Louis. International Law: Politics and Values (The Hague: Kluwer Academic Publishers, 1995).

Hilf, Meinhard and Ernst-Ulrich Petersmann. National Constitutions and International Economic Law (London: Kluwer Law International, 1993).

Hong Kong, "Enforcement of Intellectual Property Rights: Hong Kong Submission to Negotiating Group on Trade-Related Aspects of Intellectual Property Rights, Including Trade in Counterfeit Goods," MTN.GNG/NGll/W/54 (7 December 1989).

Hudec, Robert E. "Comment on 'The Club Model of Multilateral Cooperation and Problems of Democratic Legitimacy'," in R. B. Porter et al. (eds.), Efficiency, Equity, and Legitimacy: The Multilateral Trading System at the Millennium (Washington, DC: Brookings Institution Press, 2001), 297-298.

India, "Standards and Principles Concerning the Availability, Scope and Use of Trade-Related Intellectual Property Rights: Communication from India to Negotiating Group on Trade-Related Aspects of Intellectual Property Rights, Including Trade in Counterfeit Goods," MTN.GNG/NGl1/W/37 (10 July 1989a).

India, "Enforcement of Trade-Related Intellectual Property Rights: Communication from India to Negotiating Group on Trade-Related Aspects of Intellectual Property Rights Including Trade in Counterfeit Goods," MTN.GNG/NGl1/W/40 (5 September 1989b).

Jackson, John H. The World Trading System: Law and Policy of International Economic Relations (Cambridge, MA: MIT Press, 1997, 2nd ed.).

Jackson, John H. Sovereignty, the WTO, and Changing Fundamentals of International Law (Cambridge: Cambridge University Press, 2006).

Jennings, Robert and Arthur Watts. Oppenheim's International Law (London: Longman Group UK Ltd., 1992, 9th ed.).

Matthews, Duncan. "WTO Decision on Implementation of Paragraph 6 of the Doha Declaration on the TRIPS Agreement and Public Health: A Solution to the Access to Essential Medicines Problem?," 7 Journal of International Economic Law (2004), 73-107.

Musungu, Sisule F. et al., Utilizing TRIPS Flexibilities for Public Health Protection through South-South Regional Frameworks (Geneva: South Centre, 2004).

Narlikar, Amrita. World Trade Organization: A Very Short Introduction (Oxford: Oxford University Press, 2005).

Petersmann, Ernst-Ulrich. The GATT/WTO Dispute Settlement System: International Law, International Organizations and Dispute Settlement (London: Kluwer Law International, 1997).

Rein, Judy. "International Governance through Trade Agreements: Patent Protection for Essential Medicines," 21 Northwestern Journal of International Law \& Business (2001), 379-408.

Ricupero, Rubens and Ricardo Melendez Ortiz. "Preface," in UNCTAD and ICTSD (ed.), Resource Book on TRIPS and Development (New York: Cambridge University Press, 2005), vii. 
Rwanda, "Notification under Paragraph 2(a) of the Decision of 30 August 2003 on the Implementation of Paragraph 6 of the Doha Declaration on the TRIPS Agreement and Public Health," IP/N/9/RWA/1 (19 July 2007).

Shaffer, Gregory. "Recognizing Public Goods in WTO Dispute Settlement: Who Participates? Who Decides? the Case of TRIPS and Pharmaceutical Patent Protection," 7 Journal of International Economic Law (2004), 459-482.

Thapa, Rojina. "Waiver Solution in Public Health and Pharmaceutical Domain under TRIPS Agreement," 16 Journal of Intellectual Property Rights (2011), 470-476.

UN General Assembly, "Letter Dated 12 January 2015 from the Secretary-General Addressed to the President of the General Assembly" (A/69/720).

UNCTAD-ICTSD. Resource Book on TRIPS and Development (Cambridge: Cambridge University Press, 2005).

UNIDO. Public Goods for Economic Development (Vienna: UNIDO, 2008).

US, "Suggestion by the United States for Achieving the Negotiating Objective (Revision): United States Proposal for Negotiations on Trade-Related Aspects of Intellectual Property Rights," Negotiating Group on Trade-Related Aspects of Intellectual Property Rights, including Trade in Counterfeit Goods, MTN.GNG/NG11/W/ 14/Rev.1 (17 October 1988).

US, "Draft Agreement on the Trade-Related Aspects of Intellectual Property Rights: Communication from the US to Negotiating Group on Trade-Related Aspects of Intellectual Property Rights, Including Trade in Counterfeit Goods," MTN.GNG/ NGl1/W70 (11 May 1990).

Vandoren, Paul and Jean Charles Van Eeckhaute. "The WTO Decision on Paragraph 6 of the Doha Declaration on the TRIPS Agreement and Public Health: Making It Work," 6 The Journal of World Intellectual Property (2003), 779-793.

Weissman, Robert. "Long Strange Trips: The Pharmaceutical Industry Drive to Harmonize Global Intellectual Property Rules, and the Remaining WTO Legal Alternatives Available to Third World Countries," 17 University of Pennsylvania Journal of International Economic Law (1996), 1069-1125.

WHA, The 52 ${ }^{\text {nd }}$ World Health Assembly: Revised Drug Strategy, WHA52.19 (24 May 1999).

WTO, The Future of the WTO: Addressing Institutional Challenges in the New Millennium, Report by the Consultative Board to the Director-General Supachai Panitchpakdi (Geneva: WTO Publications, 2004).

WTO. World Trade Report 2009: Trade Policy Commitments and Contingency Measures (Geneva: WTO Publications, 2009).

WTO General Council, "Implementation of Paragraph 6 of the Doha Declaration on the TRIPS Agreement and Public Health," WT/L/540 and Corr.l (September 2003a).

WTO General Council, Minutes of Meeting Held in the Centre William Rappard on 25, 26, and 30 August 2003, WT/GC/M/82 (13 November 2003b).

WTO General Council, "Amendment of the TRIPS Agreement," WT/L/641 (6 December 2005).

WTO General Council, "Amendment of the TRIPS Agreement - Fourth Extension of the Period for the Acceptance by Members of the Protocol Amending the TRIPS Agreement," WT/L/899 (26 November 2013).

Yu, Peter K. "The Objectives and Principles of the TRIPS Agreement," 46 Houston Law Review (2009), 797-1046. 


\section{Cases}

Brazil - Retreaded Tyres, WT/DS332/AB/R (3 December 2007).

Canada-Pharmaceutical Patents, WT/DS114/R (17 March 2000).

China - Intellectual Property Rights, WT/DS362/R (26 January 2009).

EC - Trademarks and Geographical Indications, WT/DS290/R (15 March 2005).

US - Gasoline, WT/DS2/AB/R (29 April 1996).

US - Section 301 Trade Act, WT/DS152/R (22 December 1999).

\section{General}

Aggarwal, Aradhna. The Anti-Dumping Agreement and Developing Countries: An Introduction (New Delhi: Oxford University Press, 2007).

Bentham, J. Theory of Legislation (London: TrüBner \& Co., 1871).

Brand, Ronald A. "Sovereignty: The State, the Individual, and the International Legal System in the Twenty First Century," 25 Hastings International and Comparative Law Review (2002), 279-295.

Brooks, Roger G. and Damien Geradin. "Interpreting and Enforcing the Voluntary FRAND Commitment," 9.1 International Journal of IT Standards e Standardization Research (2011), 1-23.

Carty, Anthony. "From the Right to Economic Self-Determination to the Right to Development: A Crisis in Legal Theory," 3.5 Third World Legal Studies (1984), 73-86.

China, "Communication to the WTO TBT Committee: Intellectual Property Right (IPR) Issues in Standardization," G/TBT/W/251 (25 May 2005).

Contreras, Jorge L. "Fixing FRAND: A Pseudo-Pool Approach to Standards-based Patent Licensing," 79.1 Antitrust Law Journal (2013), 47-97.

Contreras, Jorge L. "A Market Reliancd Theory for FRAND Commitments and Other Patent Pledges," 2 Utah Law Review (2015), 479-558.

Corbin, Arthur L. Corbin on Contracts: A Comprehensive Treatise on the Working Rules of Contract Law (St. Paul: West Publishing Co., 1951, vol. IV).

Cotter, Thomas F. "Comparative Law and Economics of Standard-Essential Patents and FRAND Royalties," 22.3 Texas Intellectul Property Law Journal (2014), 311-363.

De Carvalho, Nuno Pires. The TRIPS Regime of Patent Rights (The Hague: Wolters Kluwer, 2010, 3rd ed.).

Dinwoodie, Graeme B. and Rochelle C. Dreyfuss. "Designing A Global Intellectual Property System Responsive to Change: The WTO, WIPO, and Beyond," 46 Houston Law Review (2009), 1187-1234.

Drahos, Peter. "China, the TPP and Intellectual Property," 47.1 International Review of Intellectual Property and Competition Law (2016), 1-4.

European Commission, "Guidelines on the Applicability of Article 101 of the Treaty on the Functioning of the European Union to Horizontal Co-operation Agreement," OJ C 11/01 (14 January 2011).

European Commission, "Antitrust: Commission Sends Statement of Objections to Samsung on Potential Misuse of Mobile Phone Standard-essential Patents," Press Release (Brussels, 21 December 2012).

Finger, J. Michael. Antidumping: How It Works and Who Gets Hurt (Ann Arbor: The University of Michigan Press, 1993). 
Geradin, Damien. "The Meaning of 'Fair and Reasonable' in the Context of ThirdParty Determination of FRAND Terms," 21.4 Georgy Mason Law Review (2014), 919-956.

Gervais, Daniel J. The TRIPS Agreement: Drafting History and Analysis (London: Sweet \& Maxwell, 2003, 2nd ed.).

Gervais, Daniel J. "Intellectual Property, Trade \& Development: The State of Play," 74.2 Fordham Law Review (2005), 505-535.

Ginsburg, Douglas H., Koren W. Wong-Ervin, and Joshua D. Wright. "The Troubling Use of Antitrust to Regulate FRAND Licensing," 10.1 CPI Antitrust Chronicle (2015), 2-8.

Guan, Wenwei. Intellectual Property Theory and Practice: A Critical Examination of China's TRIPS Compliance and Beyond (Heidelberg: Springer, 2014).

Hayek, F. A. The Fatal Conceit: The Errors of Socialism (London: Routledge, 1988).

Hegel, G. W. G. The Philosophy of Right, trans. T. M. Knox (Oxford: Oxford University Press, 1967).

Herr, Jochen. "Patent Litigation and Industry Standards: The Compulsory License Defense," 21.1 Intellectual Property \& Technology Law Journal (2009), 1-5.

Hindley, Brian and Patrick A. Messerlin. Antidumping Industrial Policy: Legalized Protectionism in the WTO and What to Do about It (Washington, DC: AEI Press, 1996).

India, "Standards and Principles Concerning the Availability, Scope and Use of Trade-Related Intellectual Property Rights: Communication from India to Negotiating Group on Trade-Related Aspects of Intellectual Property Rights, Including Trade in Counterfeit Goods," MTN.GNG/NGl1/W/37 (10 July 1989).

Janow, Merit E. "Trade and Competition Policy," in Patrick F.J. Macrory, Arthur E. Appleton and Michael G. Plummer (eds.), The World Trade Organization: Legal, Economic and Political Analysis (New York: Springer, 2005), 2076-2099.

Jennings, Robert and Arthur Watts. Oppenheim's International Law (London: Longman Group UK Ltd., 1992, 9th ed.).

Kesan, Jay P. and Carol M. Hayes. "FRAND's Forever: Standards, Patent Transfers, and Licensing Commitments," 89 Indiana Law Journal (2014), 231-314.

Kessler, Friedrich. "Contracts of Adhesion - Some Thoughts about Freedom of Contract," 43 Columbia Law Review (1943), 629-642.

Lloyd, P. J. "Anti-Dumping and Competition Law," in Patrick F.J. Macrory, Arthur E. Appleton and Michael G. Plummer (eds.), The World Trade Organization: Legal, Economic and Political Analysis (New York: Springer, 2005), 1666-1681.

Locke, John. The Second Treatise of Government (New Jersey: Prentice-Hall, 1997).

Maine, Henry. Ancient Law (London: J.M. Dent \& Sons Ltd., 1917).

Maskus, Keith and Stephen A. Merrill (eds.). Patent Challenges for Standard-Setting in the Global Economy: Lessons from Information and Communications Technology (Washington, DC: The National Academies Press, 2013).

Mayer, David N. "Substantive Due Process Rediscovered: The Rise and Fall of Liberty of Contract," 60 Mercer Law Review (2009), 563-658.

Narlikar, Amrita. World Trade Organization: A Very Short Introduction (Oxford: Oxford University Press, 2005).

Pedro., Roffe. "Control of Anti-Compettive Practices in Contractual Licences under the TRIPS Agreement," in Carlos M. Correa and Abdulqawi A. Yusuf (eds.), Intellectual Property and International Trade: The TRIPS Agreement (London: Kluwer Law International, 1998), 261-296. 
Peru, "Guidelines for Negotiation that Strike a Balance between Intellectual Property Rights and Development Objectives: Communication from Peru," MTN.GNG/ NGl1/W/45 (27 October 1989).

Picht, Peter. "From Transfer of Technology to Innovation through Access," in Hanns Ullrich et al. (ed.), TRIPS Plus 20: From Trade Rules to Market Principles (Heidelberg: Springer, 2016), 509-527.

Pipes, R. Property and Freedom (New York: Alfred A. Knopf, 1999).

Pound, Roscoe. "Liberty of Contract," 18.7 Yale Law Journal (1909), 454-487.

Productivity Commission, Australia, "Compulsory Licensing of Patents," (28 March 2013).

Ricupero, Rubens and Ricardo Melendez Ortiz. "Preface," in UNCTAD-ICTSD (ed.), Resource Book on TRIPS and Development (New York: Cambridge University Press, 2005), vii.

Sokol, D. Daniel and Wentong Zheng. "FRAND in China," 22 Texas Intellectual Property Law Journal (2013), 71-94.

State Administration of Industry and Commerce (SAIC), PR China. "Rules on Prohibiting Behaviors of Abuse of Intellectual Property Rights to Eliminate or Restricting Competition," (no. 2015-74, 7 April 2015).

State Intellectual Property Office, PR China. "Interim Provisions on the Administration of National Standards Involving Patents," (19 December 2013).

Sternberg, Daniel S. "A Brief History of RAND," 20.2 Boston University Journal of Science \& Technology Law (2014), 211-246.

Stiglitz, Joseph E. The Roaring Nineties: A New History of the World's Most Prosperous Decade (New York: W. W. Norton \& Company, 2003).

Supreme People's Court, PR China. "Interpretations on Several Issues Relating to Law Application in Adjudication of Patent Infringement Disputes (II)," Fashi No 1 [2016] (25 January 2016).

Trebilcock, M. J. and R. Howse. The Regulation of International Trade (London: Routledge, 2005).

UNCTAD, "Competition Policy and the Exercise of Intellectual Property," TD/B/ COM.2/CLP/68 (15 May 2008).

UNCTAD-ICTSD. Resource Book on TRIPS and Development (New York: Cambridge University Press, 2005).

UNIDO. Public Goods for Economic Development (Vienna: UNIDO, 2008).

US, "Suggestion by the United States for Achieving the Negotiating Objective (Revision): United States Proposal for Negotiations on Trade-Related Aspects of Intellectual Property Rights," Negotiating Group on Trade-Related Aspects of Intellectual Property Rights, including Trade in Counterfeit Goods, MTN.GNG/NGl1/W/ 14/Rev.1 (17 October 1988).

US DOJ \& FTC, “Antitrust Guidelines for the Licensing of Intellectual Property," (6 April 1995).

US DOJ \& USPTO, "Policy Statement on Remedies for Standard-Essential Patents Subject to Voluntary F/RAND Commitments," (8 January 2013).

US FTC, “The Evolving IP Marketplace: Aligning Patent Notice and Remedies with Competition," (March 2011).

US FTC, Interest of Amicus Curiae Filed to US Court of Appeals for the Federal Circuit, Nos. 2012-1548, 2012-1549 (4 December 2012).

US House of Representatives Committee on Ways and Means, Overview and Compilation of US Trade Statues 2013 (January 2013). 
US ITC, Notice of Final Determination: In the Matter of Certain Electronic Devices, Inv. No. 337-TA-794 (4 June 2013).

Wang, Elizabeth X.R. and Harry Foster. "An Economic Perspective of Standards and FRAND Enforcement in China," 3.sppl 1 Journal of Antitrust Enforcement (2015), il57-il71.

WTO, Doha Declaration on the TRIPS Agreement and Public Health, WT/MIN (01)/DEC/2 (14 November 2001, Doha, Qatar).

WTO, The Future of the WTO: Addressing Institutional Challenges in the New Millennium, Report by the Consultative Board to the Director-General Supachai Panitchpakdi (The Sutherland Report; Geneva: WTO Publications, 2004).

WTO, "Trade Policy Review: China, Minutes of Meeting Addendum," WT/TPR/ M/199/Add.1 (28 August 2008).

WTO, World Trade Report 2009: Trade Policy Commitments and Contingency Measures (Geneva: WTO Publications, 2009).

$\mathrm{Yu}$, Peter K. "The Objectives and Principles of the TRIPS Agreement," 46.4 Houston Law Review (2009), 797-1046.

Zhang, Guangliang. "Enforcement of F/RAND and Antitrust Intervention: Discussion from the Huawei Decisions in China," 2.6 China Legal Science (2014), 3-33.

\section{Cases}

Apple, Inc. v. Motorola Mobility, Inc., 2011 WL 7324582 (W.D.Wis. 2011).

Apple, Inc. v. Motorola Mobility, Inc., 886 F. Supp. 2d 1061 (W.D. Wis. 2012).

Brazil-Measures Affecting Desiccated Coconut, WT/DS22/R (17 October 1996).

Canada-Pharmaceutical Patents, WT/DS114/R (17 March 2000).

China - Intellectual Property Rights, WT/DS362/R (26 January 2009).

eBay, Inc. v. MercExchange, L.L.C., 547 U.S. 388, 394 (2006).

EC - Trademarks and Geographical Indications, WT/DS290/R (15 March 2005).

ESS Technology, Inc. V. PC-Tel., Inc., 1999 WL 33520483 (N.D. Cal. 1999).

Huawei v. IDC in Relation to SEPs Royalty Setting (no. 2013-305, $3^{\text {rd }}$ Civil Chamber, Shenzhen Intermediate People's Court, China).

Huawei v. IDC in Relation to Abuse of Market Dominance (no. 2013-306, $3^{\text {rd }}$ Civil Chamber, Shenzhen Intermediate People's Court, China).

Huawei v. ZTE, case C-170/13 (16 July 2015).

IMS Health GmbH \& Co. v. Commc'n, case C-418/01 (2004 E.C.R. I-5069).

Innovatio IP Ventures, LLC Patent Litig., 2013 WL 5593609 (N.D. Ill. 3 October 2013).

IPCom v. Nokia and HTC [2012] EWCA Civ 567.

Microsoft Corp. v. Motorola, Inc. 854 F.Supp.2d 993 (W.D. Wash. 2012).

Microsoft Corp. v. Motorola, Inc., 864 F.Supp.2d, 1023 (W.D. Wash. 2012).

Microsoft Corp. v. Motorola, Inc., 696 F.3d 872 (9th Cir. 2012).

Microsoft Corp. v. Motorola, Inc., No. C10-1823JLR, 2013 WL 2111217 (W.D. Wash. Apr. 25, 2013), aff'd 795 F.3d 1024 (9th Cir. 2015).

Motorola v. Apple, Case No. 6 U 136/11, Higher Regional Court of Karlsruhe, Federal Republic of Germany, 2012.

Radio Telefis Eireann v. Commc'n, C-241/91 P and C-242/91 P (1995 E.C.R. I-808).

Research in Motion Ltd. v. Motorola, Inc., 644 F.Supp.2d 788, 797 (N.D. Tex. 2008). 
Samsung v. Apple, 400367/HA ZA 11-2212, 400376/HA ZA 11-2213 and 400385/HA ZA 11-2215 (District Court of The Hague, 20 June 2012).

TiVo v. Echostar Commc'ns Corp., 446 F. Supp. 2d 664, 670 (E.D. Tex. 2006). US - Section 301 Trade Act, WT/DS152/R (22 December 1999). 